\title{
Investigating Energy Justice in Demand-Side Low-Carbon Innovations in Ontario
}

\author{
Susan Morrissey Wyse ${ }^{1}$, Runa R. Das ${ }^{2 *}$, Christina E. Hoicka ${ }^{3}$, Yuxu Zhao ${ }^{1}$ and \\ Maria-Louise McMaster ${ }^{1}$
}

${ }^{1}$ Faculty of Environmental and Urban Change, York University, Toronto, ON, Canada, ${ }^{2}$ College of Interdisciplinary Studies, Royal Roads University, Victoria, BC, Canada, ${ }^{3}$ Department of Geography, Department of Civil Engineering, University of Victoria, Victoria, BC, Canada

\section{OPEN ACCESS}

Edited by:

Edgar Liu,

University of New South

Wales, Australia

Reviewed by:

Dana Abi Ghanem,

Teesside University, United Kingdom

Neil Simcock

Liverpool John Moores University,

United Kingdom

${ }^{*}$ Correspondence:

Runa R. Das

runa.das@royalroads.ca

Specialty section: This article was submitted to

Urban Energy End-Use,

a section of the journal

Frontiers in Sustainable Cities

Received: 24 November 2020

Accepted: 07 July 2021

Published: 06 August 2021

Citation:

Wyse SM, Das RR, Hoicka CE, Zhao Y and McMaster M-L (2021)

Investigating Energy Justice in

Demand-Side Low-Carbon Innovations in Ontario.

Front. Sustain. Cities 3:633122. doi: 10.3389/frsc.2021.633122
The diffusion of low-carbon innovations, including innovative products and services, is required to accelerate a low-carbon energy transition. These innovations also have the potential to alleviate and perpetuate existing social inequities, calling into question their "justness." Energy justice is a useful analytical tool for framing justice questions related to energy. In this paper, we ask whether demand-side low-carbon energy innovations are meeting energy justice criteria. To address this question, this study develops four indicators from existing energy justice frameworks and applies them to a range of demand-side innovations offered to energy users in Ontario. The indicators are used to assess innovation availability, affordability, information, and involvement. Innovations were identified using surveys and desk research across Ontario's energy technology innovation system (ETIS). One hundred twenty-two innovations are analyzed for these four indicators, and according to intended innovation users and innovation providers. Findings suggest that three of the four indicators-availability, affordability and information are broadly being addressed, while involvement was more difficult to establish. However, the ETIS may be perpetuating inequities through an over emphasis of innovations for particular energy users, such as private businesses, alongside under-emphasis on potentially marginalized actors, such as low-income households and renters. Furthermore, government-delivered, publicly owned or regulated innovation providers place a greater emphasis on energy justice, including the provision of innovations for marginalized actors. This study aids our understanding of energy justice in low-carbon energy innovations and is critical given that in the context of funding cuts to public services, there may be an increased reliance on decentralized actors. The consideration of justice gaps that emerge through such decentralization should not be overlooked. Our findings suggest that within Ontario's ETIS, who provides innovations matters. Given the insights presented in this study, this research approach and the developed indicators could be applied to other contexts and socio-technical systems. The application of energy justice indicators, derived from existing scholarship, therefore presents an important opportunity to address current and understudied practical energy challenges.

Keywords: energy policy, low-carbon innovations, public services and governance, energy justice, low-carbon energy transitions 


\section{INTRODUCTION}

Low-carbon energy innovations, referring to novel products or services that result in lower-carbon emissions compared to established technologies (Wilson, 2018), have the potential to enable low-carbon energy transitions. Beneficially, low-carbon energy innovations (hereafter referred to as innovations) can alleviate social injustices and thus contribute to equitable energy transitioning; conversely, innovations can also perpetuate social injustices (Sovacool et al., 2019a). As such, it is critical to understand the relationship between innovations and justice, and more specifically the impact of innovations on justice concerns. In order to understand this relationship, wide consideration across the socio-technical energy system can be advantageous wherein a range of innovations, the various types of innovation users, and the various types of innovation providers are considered. Such understanding is critical given current and evolving relationships between innovation users and providers (Wolsink, 2012); increasing reliance on non-state actors in the provision of innovations and social welfare (Williams et al., 2014; Hillman et al., 2018); and the current proliferation of innovations (Karakaya et al., 2014). Research here has the potential for mitigating against emerging, as well as addressing existing, justice issues.

The justice dimensions of energy transitioning-inclusive of justice aspects "showing up" in the innovations involved in energy transitions-are increasingly important (Sovacool et al., 2019a). Specifically, over the last decade, energy justice has emerged as a concept exploring the intersection of justice, equity, and fairness in energy activities (Jenkins, 2018). Energy justice has been conceptualized in multiple ways-composed of three overarching tenets (distributive, recognition, and procedural justice) or as principles connected to energy-related decisions (e.g., availability, affordability, good governance, and due process; Sovacool and Dworkin, 2015). Through such emergent frameworks, energy justice has developed into a useful analytical tool for framing justice questions, where scholars can apply energy justice concepts, rather than merely discuss them (Jenkins, 2018). Accordingly, within energy justice scholarship, the use of indicators has been argued as promising for measuring energy justice (Sovacool and Dworkin, 2015), and for assisting decision makers with evidence-based research.

The overarching aim of this research is to investigate energy justice in low-carbon energy innovations. In this paper, we ask: Are demand-side low-carbon innovations meeting energy justice criteria? This research draws on energy justice literature and adapts justice conceptualizations to inform the study of energy justice in innovations. In particular, four energy justice principles, i.e., availability, affordability, good governance, and due process are operationalized to establish indicators to quantitatively measure the presence or absence of availability, affordability, information, and involvement, respectively, in 122 low-carbon, demand-side innovations intended for energy users in Ontario, Canada. Energy users include, for example, individuals, households, organizations, and businesses, whereas the innovation providers include governments, utilities, nonprofit organizations, and private businesses. By examining the presence or absence of energy justice in innovations, we are able to study relationships between energy users, energy providers, and the "justness" of the innovations. That is, we examine which innovations are just, which actors are providing just innovations, and which actors are receiving just innovations. This research also provides insight into distributional (i.e., by investigating how benefits such as affordability and availability are distributed to various energy users), recognition (i.e., by identifying whether potentially marginalized actors are excluded from such benefits) and procedural (i.e., by investigating who gains access to information and involvement processes) justice concerns. Further, this paper demonstrates how energy justice indicators can be derived from existing scholarly frameworks and applied to critical, current, and understudied practical challenges.

Section Introduction of this paper begins with a review of literature-section Energy Justice outlines the two frameworks employed for the development of energy justice indicators; section Innovations and Justice provides a brief overview of innovations literature, introduces the Energy Technology Innovation System (ETIS), and outlines the importance of considering the relationship between innovation users and providers from a justice perspective; and lastly, section Research Context outlines the research context of Ontario, Canada, including the four broad types of innovation providers in Ontario, and why a justice assessment is important in the Ontario context. Section Materials and Methods describes the research materials and methods, including the identification of innovations assessed in this study and the development and coding of energy justice indicators. Finally, the results are provided in section Results and discussed in section Discussion, along with a reflection on the development and application of energy justice indicators and potential limitations of the study.

\section{Energy Justice}

Energy justice has emerged primarily as an academically developed concept, where understandings of justice are applied to critical energy issues, such as energy poverty and energy security, by interdisciplinary justice scholars (Jenkins, 2018). This research employs two primary frameworks to guide study of energy justice in innovations, including in the development of energy justice indicators.

The first framework is comprised of energy justice tenets and was initially presented by McCauley et al. (2013). The authors propose energy justice as a new research agenda, one that shares the same basic philosophy with environmental and climate justice scholarship (Baasch, 2020). Here energy justice is noted to be conceptually distinct because of its particular focus on energy and its consequent aim to provide safe, affordable and sustainable energy. This triumvirate of tenets advanced by McCauley et al. include interlinked and overlapping justice themes that "have emerged in justice literature for energy policy" (p. 2) and include: (1) distributional justice, which recognizes the unequal distribution of costs and benefits; (2) recognition justice, which is concerned with the fair consideration and representation of people in vulnerable circumstances, where such vulnerability may be worsened through a given process; and (3) procedural justice, 
concerning the ability of all groups to participate in, and impact, decision-making (McCauley et al., 2013; Sovacool et al., 2019b). Since its introduction, scholars have advanced modifications to the tenets. A later contribution from Jenkins et al. (2016) emphasizes the order of these tenets, i.e., the "what, who and how," while other scholars have added additional justice tenets, including cosmopolitan justice, which is a universal approach centered on the protection of all human beings (e.g., global externalities; Sovacool et al., 2019a) and restorative justice, which focuses on the response to injustices through reparation of harm done rather than punishment (Heffron and McCauley, 2017).

The second framework for understanding energy justice has been advanced by Sovacool and co-authors. Sovacool and Dworkin (2015), first developed an energy justice framework by connecting energy policy and technology concerns with eight philosophical concepts from classical theorists and modern thinkers, including, for example, Kantian ethics, utilitarianism, and libertarianism. The overarching concepts-virtue, utility, human rights, procedural justice, welfare, freedom, posterity, and responsibility-inform the development of a principles-based account of energy justice: availability, affordability, due process, good governance, sustainability, intra-generational equity, intergenerational equity, and responsibility. The order of these principles is not based on importance, rather, it starts with the "simplest and most accepted ones" before moving toward the "more controversial and complex" (p. 439). Sovacool et al. (2017) add two additional principles-resistance and intersectionalitywhich follow an exploration of non-Western justice theorists, thereby addressing a critique levied against energy justice theory as being derived from Western, European, and American thinkers, with the exclusion of scholarship from the Global South (McCauley et al., 2018).

The continued evolution of these frameworks reflects the fluid nature of justice considerations across time, place and perspective, where what is seen to be "just" varies to such an extent that developing a static categorization may not be achievable, nor even desirable. However, while conceptualizing energy justice remains a challenge, the frameworks and categorizations emerging within energy justice literature provide a useful tool for analyzing particular contexts and challenges (Sovacool and Dworkin, 2015), particularly in areas of research where justice considerations have largely been absent.

In order to develop the indicators in this study, our research draws primarily from Sovacool and coauthors' energy justice principles. However, in keeping with Sovacool and Dworkin (2015), who emphasize the mesh of energy justice tenets inherent in their framework of principles, our indicators provide insights for both theoretical frameworks. Our study draws from the principles: availability, affordability, due process and good governance. These principles were selected for two reasons: first, these four principles, when considered across various end-users within an innovation system, provide insight into the three main tenets associated with energy and environmental justice: distributional, recognition, and procedural justice (McCauley et al., 2013; Baasch, 2020). Specifically, by considering these indicators in relation to the various types of energy users in a socio-technical system, we can gain an understanding of how benefits, such as availability and affordability are distributed; whether potentially marginalized actors are being excluded from such benefits, i.e., recognition (Sovacool et al., 2019b); and who gains access to information and involvement processes, which are components of procedural justice (Sovacool and Dworkin, 2015). Secondly, these indicators were selected based on the availability of data, given that the methods outlined in section Materials and Methods do not allow for consideration of all principlesfor example, resistance would not be able to be assessed given the available dataset. It should be noted, however, that due to the fluidity of justice principles outlined above, a complete representation of justice likely would not be possible, even with the inclusion of all principles or tenets.

\section{Innovations and Justice}

Eco innovations, a term that is used synonymously with lowcarbon, green, sustainable, and environmental innovations, are defined as the "creation or implementation of new, or significantly improved, products, processes, marketing methods, organizational structures, and institutional arrangements which lead to environmental improvements compared to relevant alternatives" (OECD, 2009 as cited in Karakaya et al., 2014, p. 394). These innovations not only have the potential to contribute to low-carbon energy transitions, they also have the potential to contribute to equitable transitions by positively affecting users. This can be seen in the case of innovations for addressing energy poverty. Energy poverty-broadly referring to the inability of households to meet their energy needs, including households in industrialized nations (Bouzarovski et al., 2012; Bednar and Reames, 2020) - has been shown to fall disproportionately on low-income and racialized communities (Drehobl et al., 2020). Depending on their implementation, innovations here have the potential to address energy poverty through, for example, enabling retrofits for communities to reduce their spending on energy (Bednar and Reames, 2020). Nonetheless, if justice considerations are not a priority in the design and diffusion of innovations, innovations may exasperate injustices. For example, regressive funding arrangements raise average shelter costs while only addressing energy affordability for a small portion of vulnerable households, thereby worsening increasing overall costs for many low-income households (Gillard et al., 2017). Another example involves energy literacy, where critical knowledge gaps in communities are associated with the inability to participate in energy decision-making processes, such as voting or public meetings (Bozuwa, 2019). Innovations have the potential to contribute to knowledge-building through, for example, educational training for members of renewable energy cooperatives (Johnson and Lewis, 2017). Conversely, such innovations may also exasperate injustices when knowledgebuilding initiatives are unavailable to marginalized actors-for example, renewable energy cooperatives have historically seen an underrepresentation of low-income, racialized communities (Johnson and Lewis, 2017), and women (Fraune, 2015).

Within sustainability transitions theory, the Energy Technology Innovation System (ETIS) is a framework that describes a systems perspective of innovation, including innovation emergence and diffusion, as well as the various actors, 
networks and institutions involved in innovation processes (Sims Gallagher et al., 2012; Grubler and Wilson, 2013). This framework, which has already been employed in the Canadian context by Jordaan et al. (2017), is used in this study to identify Ontario demand-side low-carbon innovations. The ETIS is noted to have different structures in different contexts; in other words, dynamic relationships exist between innovation users and innovation providers and these vary in different contexts (Sims Gallagher et al., 2012). This is relevant to our research because the specific actors (i.e., innovation users and providers) involved within a given ETIS can impact the justice aspects of innovations.

From a justice perspective, there are multiple reasons why the type of innovation provider is important for energy users. For example, Reames (2016) notes that energy users' (e.g., households') lack of trust in particular types of providers may be a barrier to innovation uptake in communities that have historical or socioeconomic reasons for social exclusion (e.g., low-income or otherwise marginalized communities). LaceyBarnacle and Bird (2018) considered the role of providersspecifically, intermediary organizations ${ }^{1}$ - from an energy justice perspective, arguing that intermediaries have the potential to act as a "critical bridge" by engaging marginalized communities and otherwise excluded community groups. However, they also note that the ability of intermediaries to address key justice concerns is highly dependent on funding support through multiple levels of government, which is hampered during times of austerity. The increasing reliance on providers that are not governmentowned or heavily regulated has also been criticized on the basis that it represents a form of "roll-back neoliberalism" occurring alongside significant funding cuts to critical public services (Williams et al., 2014). In this context, there can be unwillingness to critically consider possible justice gaps emerging out of decentralized and localized actor involvement in traditionally government-led energy initiatives (Catney et al., 2014). Furthermore, as energy transitions continue to advance, the participation of energy users in low-carbon demandside innovations requires engagement with new information, relationships, and transactions. Hence, participation in these options requires current relationships between consumers and conventional energy providers to change and new relationships to emerge (Wolsink, 2012). Moreover, such changes have the added potential to contribute to just paths by increasing the likelihood of various types of actors (including those that are marginalized) being acknowledged and included in key developments, as well as gaining from them.

The 2019 research agenda of the Sustainability Transition Research Network (STRN) emphasizes the irreducible impact of transitions on notions of equity and justice, while noting that attention drawn to this impact has been limited (Köhler et al., 2019). They have advanced a call for research "engaging explicitly with ethical considerations that arise from sustainability

\footnotetext{
${ }^{1}$ Intermediary organizations are typically defined by the functions they performfor example, demand articulation, network building, capacity building, innovation process management, knowledge brokering, and institutional support (Hannon et al., 2014). In the ETIS, innovation intermediaries (Gliedt et al., 2018) are important actors in the development and delivery of demand-side innovations.
}

transitions" (p. 16). Recently, Sovacool et al. (2019a) explored the relationship between justice and low-carbon innovations by assessing energy justice in four innovations: energy services contracting, electric vehicles, solar photovoltaic panels, and lowcarbon heating. These innovations were examined according to four justice principles: affordability, sustainability, equity, and respect. Their investigation reveals that innovations may carry opportunities to alleviate injustices while simultaneously contributing to another type of injustice. For example, electric vehicles reduce carbon emissions, air pollution and fuel usage, but are not equally accessible to all people due to cost and charging barriers. A further study from Sovacool et al. (2019b) employs a tenet-based framework (including distributive, procedural, cosmopolitan and recognition justice) and identified 120 distinct injustices associated with four European low-carbon transitions, including nuclear power, smart meters, electric vehicles and solar energy. As energy transitions continue to advance, with a more diverse array of actors involved than in traditional energy systems (Brisbois, 2020), the relationship between innovation users and innovation providers will be critical to understand from an energy justice perspective. Thus, the current research contributes to literature by investigating potential justice gaps that may emerge in evolving relationships between innovation users and providers in a given sociotechnical context, by specifically taking into account different innovation user and provider dynamics.

\section{Research Context}

The research context is Ontario, Canada's most populous province of $\sim 14.6$ million, and where energy sectors (natural gas and electricity) are predominantly provincially regulated. Ontario's energy system-a "hybrid" approach-encompasses both central planning and market competition (OEB, 2020). The electricity system, in particular, began a shift toward centralized planning and management in 2003 (Ontario Ministry of Energy, 2017), with conservation programs centrally managed by the Independent Electricity System Operator (IESO). Over the study timeframe, climate change policy comprised a patchwork of federal and provincial policy frameworks and actions that consisted mainly of sector specific programs. With respect to innovation, Ontario's Innovation Agenda (Ontario, 2008), advanced by the provincial government, articulates a strategy to develop energy technology, among other areas of innovation. Ontario's Innovation Agenda also supports social enterprises, a collective term for a range of organizations seeking market-based solutions for social problems (Hillman et al., 2018), and which have long been involved in climate change and energy policies and services (Gliedt and Parker, 2014).

Given the context-specific nature of the aforementioned dynamic relationships between innovation users and providers within the ETIS, the following subsections detail key trends in Ontario regarding innovation providers, as well as the relationships between providers and users, over the study timeline. Within Ontario's ETIS, four main types of providers of low-carbon innovations are: (1) governments, (2) utilities, (3) non-profit organizations, and (4) private businesses. Innovation users may include, for example, households 
(including renters and low-income households, individuals, non-profit organizations, and public sector institutions. The following section details the role of innovation providers in their support for these types of energy users in the Ontario context.

\section{Governments}

Environmental and climate change policy was subject to stops and starts at both the federal and provincial levels. Generally, Liberal governments have committed to either international or regional climate change agreements or markets and targets, while Conservative governments have refused to participate in such agreements or markets. Many municipalities have taken leadership on climate change mitigation and action through networks such as the Federation of Canadian Municipalities and International Council for Local Environmental Initiatives Canada.

All levels of government (federal, provincial, and municipal) have been involved in providing innovations. For example, programs for energy users, such as the EnerGuide for Houses and ecoEnergy programs were designed by Natural Resources Canada from 1998 to 2012 to encourage homeowners to reduce their GHG emissions via home energy efficiency retrofit investments (Hoicka et al., 2014). Ontario's provincial government put forward the Green Energy and Green Economy Act (GEGEA), which established Canada's first feed-in-tariff program, and the 2016 Climate Change Mitigation and Low-carbon Economy Act established the country's second provincial cap and trade program, the proceeds from which funded numerous other innovations to address energy and climate change. Municipal governments have also offered programs, such as the Home Energy Loan Program for energy efficiency retrofits from the City of Toronto. Ontario has also seen the uptake of municipal energy plans funded by the Government of Ontario's Municipal Energy Plan Program (Wyse and Hoicka, 2019). Furthermore, through the Municipal Act, Ontario gave municipalities new greenhouse gas emission reporting responsibilities and powers to use local improvement charges to assist financing of energy projects through municipal tax bills (Ministry of Municipal Affairs and Housing, 2012).

\section{Utilities}

Over the study timeframe, there were 80 local electricity distributors operating in Ontario, all licensed by the Ontario Energy Board (OEB) — of these, 77 are also regulated by the OEB (Ontario Distribution Sector Review Panel, 2012). These utilities serve energy users directly, and electricity distribution lines have been predominantly owned and managed by municipalities for over a century (Ontario Distribution Sector Review Panel, 2012). Ontario had three major natural gas distribution utilities (now merged into two) that serve natural gas customers and also regulated by the OEB (2012). A large majority of Ontarians (roughly 95\%) bought electricity and natural gas from utilities, with these utilities not being permitted to make a profit from the sale of electricity or natural gas (OEB, 2020). Conservation programs available during the study timeframe were provincially regulated and rolled out by utilities. Natural gas utilities began offering demand-side management programs in the mid-1990s
(IndEco Navigant Consulting, 2017). Following the push for electricity conservation in 2005 , conservation programs were delivered by local electricity distribution companies. One policy, implemented by utilities starting in 2004, was a ministerial directive to implement smart meters across the province by 2010 to provide real-time information on electricity usage to manage responses to time variant energy prices (Ontario Minister of Energy, 2004). The installation of smart meters in 4.8 million homes cost the province roughly $\$ 1.9$ billion (Crawley, 2014). Lastly, 100 Indigenous community energy plans also received funding from the IESO's Indigenous Community Energy Plan program (Wyse and Hoicka, 2019), which was announced in conjunction with the Municipal Energy Plan Program in the province's Long-Term Energy Plan (Ministry of Energy, 2013).

\section{Non-profit Organizations}

Non-profit organizations have played a critical role in filling the gaps created by provincial government cost-cutting (Brouard et al., 2015). For example, non-profit organizations such as Green Communities Canada and the Residential Energy Efficiency Project were deeply involved in the delivery of the federal EnerGuide for Houses and ecoEnergy programs (Hoicka et al., 2014). Further, the GEGEA that created the feed-in-tariff program with benefits for community-based groups created opportunities for social enterprises in the energy sector. Support for the non-profit sector in Ontario has included numerous networks and funding agencies. However, Brouard et al. (2015) note that "the dominant formulation of social enterprise in Ontario, especially from the point of view of funding bodies, is one that focuses on individual entrepreneurs creating successful businesses that have, as an element, a broadly construed social purpose (e.g., employment or environmental need)" (p. 65).

\section{Private Businesses}

Ontario's Innovation Agenda (Ontario, 2008) articulated the desire to develop innovation. Further, the agenda developed networks to encourage researchers, entrepreneurs, and businesses with a streamlined approach of client-based services to commercialize innovations (Hepburn, 2013). One prominent example was the Green Button Initiative. This program was developed by the province's innovation hub (MaRS) in order to encourage "standardized and secure access to smart meter data (that) would leverage the province's global-leading investment in the smart grid and would open up the sector to innovative solutions for energy conservation" (Bordeaux and Vesta, 2015). It had the goal of having third party service providers enter the market to provide services that encourage behavior change among customers.

\section{Energy Users and Justice Concerns in Ontario Context}

Ontario is also an important context to investigate due to the presence of numerous energy justice concerns for energy users. Concerning the distribution of costs for households, for example, while Ontario's energy poverty rate has been estimated to be roughly 7\% (Canada Energy Regulator, 2017), energy poverty is experienced more frequently by Ontario's rural 
energy users (Scott, 2016) as well as racialized and Indigenous peoples (CUSP, 2019). Further, low-income households, which are far more likely to experience and be harmed by energy poverty, are estimated to be $14.4 \%$ of Ontario's population (Statistics Canada, 2017). Low-income households are more likely to be renters (Canadian Rental Housing Index, 2018), and face a higher risk of missing electricity payments-for example, in 2015, 60,000 Ontario homes had their power shut off for failing to make payments (Habitat for Humanity HaltonMississauga, 2018). Given such challenges, it may be unsurprising that electricity prices have been a flashpoint within Ontario's politics (e.g., Bowes, 2016; O'Shea, 2016). Problems with meaningful community involvement have also been documented in Ontario. For example, the GEGEA has been criticized on the grounds that centralized, top-down development processes have perpetuated procedural injustices, where communities have been excluded from decision-making processes, contributing to deepened feelings of disempowerment and marginalization (McRobert et al., 2016; Walker and Baxter, 2017). Further, the IESO's Indigenous Community Energy Plan program was argued to employ an overly top-down approach lacking meaningful participation and consideration of "local needs, values and resources” (Rakshit et al., 2018, p. 21).

\section{MATERIALS AND METHODS}

This section outlines the materials and methods used in this research. The unit of analysis is the demand-side low-carbon innovation. One hundred and twenty-two innovations were identified using two methods, described in detail in section Identification of Innovations. The innovations were then assessed according to an energy justice framework detailed in section Development and Coding of Energy Justice Indicators.

\section{Identification of Innovations}

The methods involved in the identification of innovations are outlined here and a more detailed description is available in the Hoicka et al. (2021). In Hoicka et al. (2021), which focuses on understanding the potential of low-carbon innovations aimed at the demand-side (i.e., end users) to impact socio-technical system change, the ETIS framework was employed to identify low-carbon innovations. Within the ETIS, a policy domain can be used to identify a regime boundary within which governments and institutions deploy policies (Matti et al., 2017). The policy domains that are typically investigated by ETIS studies include energy, environmental, science, technology and innovation, and industrial policy, but they vary by ETIS and are context dependent, defined by the institutions in a particular context. Innovations offered during the 2003-2018 timeframe comprise the scope of this research. In June 2018, a conservative provincial government was elected and many policies were reversed or rescinded; innovations post-election are therefore not considered. The ETIS policy domains specific to the Ontario context that influence the diffusion of low-carbon innovations for the demand-side were: climate change; energy; industrial and science, technology, innovation; and social enterprise and social innovation.
Innovations were identified using a combination of two approaches:

- Desk research was conducted to identify institutions (across federal, provincial and municipal scales) and their associated legislations, plans, strategies, and policy frameworks; actors and networks; and the aspirational demand-side innovations identified in these documents. This research also identified experts across the four policy domains who were sent a survey.

- Two surveys were used. A first survey was sent to identified experts belonging to the four policy domains including individuals belonging to intermediaries (i.e., accelerator and incubator centers); municipal, provincial or federal governments; regulators and system operators; universities and research institutes; utilities; non-profit organizations; consultants and other private businesses. Participants were asked to identify innovations available to Ontario's energy users that have the potential to make an important contribution to a transition to a low-carbon energy system. A second survey was next sent to the providers of innovations themselves and the identified innovations.

The scope of the current analysis is based on data resulting from the first survey, wherein 475 surveys were sent to individuals with 135 responding and resulting in the identification of 90 innovations relevant to this analysis; 32 innovations relevant to this analysis were additionally identified solely through desk research.

\section{Development and Coding of Energy Justice Indicators}

A dataset of innovations was developed wherein each innovation was coded according to publicly available sources, such as innovation websites and government policy documents. Innovations were then coded according to our framework for assessing energy justice, which draws from Sovacool and coauthors framework for understanding energy justice (Sovacool and Dworkin, 2015; Sovacool et al., 2016, 2019a). Four indicators-availability, affordability, information, and involvement-were developed in relation to four corresponding energy justice principles (see Table 1). As is outlined in section Energy Justice, the particular principles were selected due to their applicability to the three main tenets of energy justice (McCauley et al., 2013), as well as the characteristics of the available data. The research employed binary coding, rather than a scaled approach, given the innovations research and the survey from the outset did not set out or have the particular objective of examining the justice components or using a justice framework for examining Ontario's innovations. Therefore, each innovation in our sample was coded for the "presence" or "absence" of availability, affordability, information, and involvement-our measures of energy justice. Thus, each energy justice indicator was measured as a binary 1-0 outcome for each type of innovation user. Table 2 provides examples of coded text for each energy justice indicator. Coding of justice 
TABLE 1 | Energy justice indicators.

\begin{tabular}{|c|c|c|c|}
\hline Indicator & Coding approach for assessing indicator & Principle & Definition of principle \\
\hline Availability & $\begin{array}{l}\text { This indicator assesses whether the innovation aims to improve } \\
\text { provision of supply, infrastructure, energy efficiency, conservation, } \\
\text { transportation, storage, and/or distribution of energy. This includes, for } \\
\text { example, the availability of energy efficiency technologies or electric } \\
\text { vehicle infrastructure. This does not include, for example, information } \\
\text { about the provision of supply, infrastructure, energy efficiency, } \\
\text { conservation, transportation, storage, and/or distribution of energy. }\end{array}$ & Availability & $\begin{array}{l}\text { Broadly, availability draws from the idea that "people deserve } \\
\text { sufficient energy resources of high quality" (Sovacool et al., } \\
\text { 2016). Sovacool and Dworkin (2015) emphasize concerns } \\
\text { related to supply and reliability, as well as technological } \\
\text { innovations enhancing conservation, transportation, storage, } \\
\text { and distribution of energy, including investment in such } \\
\text { factors. }\end{array}$ \\
\hline Affordability & $\begin{array}{l}\text { This indicator assesses whether the innovation aims to reduce } \\
\text { cost/improve affordability of supply, infrastructure, conservation, } \\
\text { transportation, storage, and/or distribution of energy for each user } \\
\text { type. This includes, for example, improved affordability through financial } \\
\text { incentives. }\end{array}$ & Affordability & $\begin{array}{l}\text { Affordability draws from the idea that "the provision of energy } \\
\text { services should not become a financial burden for } \\
\text { consumers, especially the poor" (Sovacool et al., 2016). } \\
\text { Furthermore, affordability concerns energy bills that do not } \\
\text { overly burden consumers, as well as stable and equitable } \\
\text { prices (Sovacool and Dworkin, 2015). }\end{array}$ \\
\hline Information & $\begin{array}{l}\text { This indicator assesses whether or not the innovation aims to provide } \\
\text { "active" information about supply, infrastructure, conservation, } \\
\text { transportation, storage, and/or distribution of energy for each user type. } \\
\text { This includes, for example, proactive provision, information resulting } \\
\text { from energy audits, capacity-building initiatives, or lobbying. The } \\
\text { indicator does not incorporate "passive" information, such as general } \\
\text { information provided on publicly available websites; however, this is } \\
\text { discussed as an element of transparency in the discussion section. }\end{array}$ & $\begin{array}{l}\text { Good } \\
\text { governance }\end{array}$ & $\begin{array}{l}\text { Sovacool and Dworkin (2015) identify "good governance" as } \\
\text { a principle of energy justice, where access to information } \\
\text { about energy and the environment is a central element of } \\
\text { "good governance." }\end{array}$ \\
\hline Involvement & $\begin{array}{l}\text { This indicator assesses whether or not each type of actor was involved } \\
\text { (through engagement and consultation efforts) in the development of } \\
\text { the innovation. }\end{array}$ & $\begin{array}{l}\text { Due } \\
\text { Process }\end{array}$ & $\begin{array}{l}\text { Due process, for the purposes of this research, draws } \\
\text { primarily from the idea that "communities must be involved in } \\
\text { deciding about projects that will affect them" (Sovacool and } \\
\text { Dworkin, 2015). }\end{array}$ \\
\hline
\end{tabular}

TABLE 2 | Examples of coded text for each indicator.

\begin{tabular}{|c|c|c|}
\hline Indicator & Fragment of coded text & Coding approach \\
\hline Availability & $\begin{array}{l}\text { "Participation is easy, and includes the installation of a switch that allows us to send a } \\
\text { signal to either your electric water heater to temporarily delay the heating of water or } \\
\text { central air conditioner to temporarily cycle on and off the compressor in your unit. As } \\
\text { an added incentive, you will receive your choice of a FREE in-home display (IHD) that } \\
\text { will allow you to monitor your energy consumption" (Community Conservation } \\
\text { Manager, 2018). }\end{array}$ & $\begin{array}{l}\text { Given the provision of energy efficiency technologies to } \\
\text { energy users, this innovation was coded as addressing the } \\
\text { availability indicator for the eligible types of energy users. }\end{array}$ \\
\hline Affordability & $\begin{array}{l}\text { "Homeowners can get a low-interest loan of up to } \$ 75,000 \text { to cover the cost of home } \\
\text { energy improvements" (Toronto, 2017). }\end{array}$ & $\begin{array}{l}\text { Given the aim to overcome cost barriers for energy efficiency, } \\
\text { this innovation was coded as addressing the affordability } \\
\text { indicator for the eligible types of energy users. }\end{array}$ \\
\hline Information & $\begin{array}{l}\text { "This includes activities such as awareness campaigns, material and course } \\
\text { development, and education workshops. These projects help equip communities and } \\
\text { organizations with knowledge and training, creating opportunities for them participate } \\
\text { in Ontario's energy sector" (IESO, 2017). }\end{array}$ & $\begin{array}{l}\text { Given the provision of active information (i.e., educational } \\
\text { workshops) about energy activities, this innovation was } \\
\text { coded as addressing the information indicator for the eligible } \\
\text { types of energy users. }\end{array}$ \\
\hline Involvement & $\begin{array}{l}\text { "The list of invitees included architects, engineers, developers, builders, environmental } \\
\text { groups, and property owners, and/or managers (particularly of large amounts of } \\
\text { property in Toronto, such as the Toronto District School Board)" (Toronto, 2006). }\end{array}$ & $\begin{array}{l}\text { Given the involvement of the identified actors in consultation } \\
\text { efforts, this innovation was coded as addressing the } \\
\text { involvement indicator for private businesses, non-profit } \\
\text { organizations, and institutions. }\end{array}$ \\
\hline
\end{tabular}

indicators was completed by the first author, with support from co-authors.

By developing energy justice indicators derived from existing scholarly frameworks, we provide a method for measuring energy justice, in consideration of various innovation users and innovation providers (see Table 3). This measurement can contribute to understanding energy justice in low-carbon energy innovations, within a given socio-technical system, and thus demonstrate how energy justice can be applied to critical, current, and understudied practical challenges.

\section{RESULTS}

This study assessed 122 demand-side innovations available to Ontario's energy users, which we have categorized according to the aim of the innovations. The aim of the innovation refers to the specific contribution to low-carbon energy transitions advanced by the given innovation (e.g., the advancement of battery storage; see Table 4). An example is provided to demonstrate how each specific aim may be advanced by an innovation. 
TABLE 3 | Various actors involved within the Ontario ETIS innovation system.

\begin{tabular}{|c|c|c|}
\hline Actor category & Actor types assessed & Assessment approach \\
\hline Innovation users ${ }^{a}$ & $\begin{array}{l}\text { (1) Governments (including federal, provincial and municipal), (2) homeowners, (3) low-income } \\
\text { households, (4) renters, (5) Indigenous communities }{ }^{\text {b }} \text { (including First Nation and Métis } \\
\text { communities), (6) individuals (including targeted members of the public that are not explicitly } \\
\text { included in other subcategories such as homeowners or renters), (7) public sector institutions } \\
\text { (including school boards, universities, colleges, libraries, and hospitals) }{ }^{c} \text {, (8) non-profit } \\
\text { organizations, (9) private businesses (including industry, consultants and other private } \\
\text { businesses), and (10) utilities (including natural gas, electricity utilities, and planning authority). }\end{array}$ & $\begin{array}{l}\text { The presence or lack of presence of each } \\
\text { energy justice indicator was coded for } \\
\text { each type of innovation user. One } \\
\text { innovation may be intended for multiple } \\
\text { types of energy users. }\end{array}$ \\
\hline Innovation providers & $\begin{array}{l}\text { (1) Governments (including federal, province of Ontario and municipal), (2) non-profit } \\
\text { organizations, (3) private businesses, and (4) utilities (including natural gas distributors, } \\
\text { electricity distribution companies, and the planning authority). }\end{array}$ & $\begin{array}{l}\text { Each innovation was coded according to } \\
\text { what type of actor provided the innovation. } \\
\text { One innovation may be provided by } \\
\text { multiple types of actors (e.g., one } \\
\text { innovation may be provided by a } \\
\text { partnership between a business and a } \\
\text { non-profit organization). }\end{array}$ \\
\hline
\end{tabular}

a These categories emerged from the data, rather than being pre-determined, and correspond with the documented users of a given innovation.

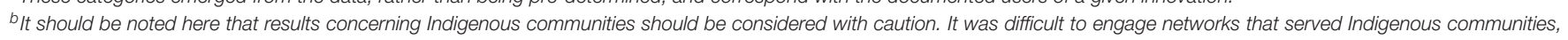

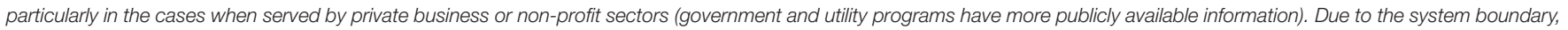
remote communities were not addressed by this research.

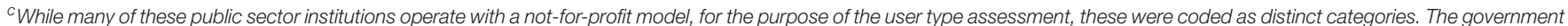

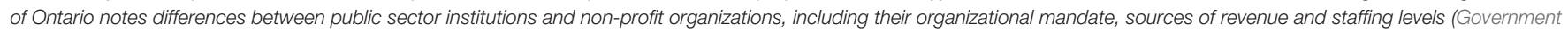
of Ontario, 2019), which warrant distinct consideration from a justice standpoint.

Of the 122 innovations analyzed, 36 were provided by governments (federal, provincial or municipal), 38 by non-profit organizations, 28 by private businesses (including industry and industry associations), and 47 by utilities (including electricity and natural gas utilities and the provincial system operator and planning authority). Reference populations, i.e., the larger group, to which an analytic sample is being compared (Schmidt and Pardo, 2014), for these innovation providers are as follows: 444 municipal governments, 1 provincial government, 1 federal government, 59,605 non-profit organizations, 1,063,756 private businesses, and 77 utilities (Hoicka et al., 2021).

\section{Presence of Energy Justice in Low-Carbon Energy Innovations}

This section concerns whether the 122 demand-side low-carbon energy innovations are meeting energy justice criteria. Almost all (98\%) of the innovations demonstrated presence of either:

(1) Aiming to improve availability of supply, infrastructure, energy efficiency, conservation, transportation, storage, and/or distribution of energy;

(2) Aiming to reduce cost/improve affordability of supply, infrastructure, energy efficiency, conservation, transportation, storage, and/or distribution of energy for energy users;

(3) Aiming to provide targeted information about supply, infrastructure, conservation, transportation, storage, and/or distribution of energy to energy users; or

(4) Involving various actor types through engagement and consultation in the development of the innovation.

Further, each innovation demonstrated between 0 and 4 of the energy justice indicators and, on average, each innovation in this sample demonstrated 2 of the energy justice indicators. A chi-square test of independence was conducted to examine the differences between the presence of justice indicators in the Ontario innovations and significant differences were found $\left(\chi^{2}=186.86\right.$, $\left.d f=6, p<0.05\right)$. As shown in Table 5, information provisioning was present in $63 \%$ of the innovations, compared to availability in $59 \%$, affordability in $56 \%$, and involvement in $40 \%$ of the innovations. Thus, the data show moderate majorities for information, availability and affordability. Involvement was "unknown" for $54 \%$ of the innovations, in contrast with $3 \%$ unknown for all other energy justice indicators.

\section{Presence of Energy Justice Across Innovation Users}

This section concerns how the 122 demand-side low-carbon energy innovations are meeting energy justice criteria in relation to the targeted innovation users. Results demonstrate that availability, affordability, information, and involvement of the demand-side innovations vary according to which energy user type is on the receiving end of the innovations. In particular, innovation availability, affordability, information, and involvement were present most frequently in the innovations provided to private businesses. Conversely, innovation availability, affordability, information, and involvement were present less for low-income households, renters and Indigenous communities. The relationship between the presence of justice in innovations and user type was not tested given that cell counts for some cells were 0 .

\section{Presence of Energy Justice Across Various Innovation Providers and Users}

This section first concerns how the 122 demand-side lowcarbon energy innovations are meeting energy justice criteria in relation to the provider of the innovation. Of the innovations 
TABLE 4 | Description of innovations in the sample.

\begin{tabular}{|c|c|c|c|}
\hline $\begin{array}{l}\text { Aim of the } \\
\text { innovations }\end{array}$ & Description & $\begin{array}{l}\text { \# of } \\
\text { innovations }\end{array}$ & Example innovation \\
\hline Battery storage & $\begin{array}{l}\text { These serve to balance supply and demand within energy systems, and } \\
\text { ease the points of congestion (IESO, 2021a). }\end{array}$ & 6 & Community energy storage \\
\hline $\begin{array}{l}\text { Demand-side } \\
\text { management }\end{array}$ & $\begin{array}{l}\text { The modification of consumer demand for natural gas or electricity through } \\
\text { various methods such as financial incentives, education, and other } \\
\text { programs (OEB, 2008). }\end{array}$ & 28 & $\begin{array}{l}\text { Culture of conservation-unplug your } \\
\text { stuff campaign }\end{array}$ \\
\hline District energy & $\begin{array}{l}\text { Networks that involve "multi-building heating and cooling, in which heat } \\
\text { and/or cold is distributed by circulating either hot water or low-pressure } \\
\text { steam through underground piping" (Rezaie and Rosen, 2012, p. 3) }\end{array}$ & 1 & $\begin{array}{l}\text { Combined heat and power (CHP) } \\
\text { incentives }\end{array}$ \\
\hline Electric vehicles & $\begin{array}{l}\text { Any vehicle that is partially or entirely powered by electricity and plugs in to } \\
\text { recharge (Ministry of Transportation, 2009). }\end{array}$ & 9 & $\begin{array}{l}\text { Electric vehicle suitability } \\
\text { assessments }\end{array}$ \\
\hline $\begin{array}{l}\text { Electric vehicle } \\
\text { charging stations }\end{array}$ & $\begin{array}{l}\text { Charging stations for electric vehicles (e.g., at home, at work or at public } \\
\text { charging stations; Ministry of Transportation, 2009). }\end{array}$ & 3 & $\begin{array}{l}\text { Electric vehicle chargers grant } \\
\text { programs }\end{array}$ \\
\hline Energy efficiency & $\begin{array}{l}\text { "The ratio of useful energy output/energy input, usually defined as a } \\
\text { percentage. The more efficient a device is, the less energy is lost, which } \\
\text { allows less energy to be used to produce an energy service" (Hoicka and } \\
\text { MacArthur, 2021). While energy efficiency may be a component of an } \\
\text { energy demand reduction strategy, it is coded as conceptually distinct } \\
\text { within this study. }\end{array}$ & 68 & $\begin{array}{l}\text { Financing of energy efficiency retrofits } \\
\text { through local improvement charges }\end{array}$ \\
\hline Local energy plans & $\begin{array}{l}\text { A process to develop "strategic vision documents that outline the energy } \\
\text { goals of a local context or community" (Wyse and Hoicka, 2019) }\end{array}$ & 7 & $\begin{array}{l}\text { Capacity-building for smart energy } \\
\text { communities }\end{array}$ \\
\hline Microgrids & $\begin{array}{l}\text { A small grid with generation, consumption, and sometimes storage that can } \\
\text { operate in a grid-connected and "isolated" mode (Palensky and Kupzog, } \\
\text { 2013) }\end{array}$ & 2 & Micro-grid demonstration project \\
\hline $\begin{array}{l}\text { Natural gas } \\
\text { infrastructure }\end{array}$ & $\begin{array}{l}\text { Infrastructure that supports the transportation of natural gas through } \\
\text { pipelines to local utilities (OEB, 2012). }\end{array}$ & 1 & Natural gas grant program \\
\hline New construction & $\begin{array}{l}\text { The building of new and substantially renovated buildings (Cadmus, } \\
\text { Econoler and Apex Analytics, 2018). }\end{array}$ & 7 & $\begin{array}{l}\text { Energy efficiency incentives for new } \\
\text { construction }\end{array}$ \\
\hline Program design & $\begin{array}{l}\text { The design of specific programs that contribute to, for example, energy } \\
\text { efficiency, or demand-side management. }\end{array}$ & 1 & Energy efficiency consultancy \\
\hline $\begin{array}{l}\text { Public/shared/alternative } \\
\text { transportation }\end{array}$ & Includes public, shared, and sustainable transportation services. & 7 & Community bike sharing services \\
\hline $\begin{array}{l}\text { Renewable energy } \\
\text { (location not } \\
\text { specified) }\end{array}$ & $\begin{array}{l}\text { Energy derived from natural processes that are replenished at a rate that is } \\
\text { equal to or faster than the rate at which they are consumed (Government of } \\
\text { Canada, 2017). }\end{array}$ & 19 & $\begin{array}{l}\text { Energy efficiency retrofits for rooftop } \\
(\mathrm{PV}) \text { solar }\end{array}$ \\
\hline $\begin{array}{l}\text { Renewable energy } \\
\text { (onsite) }\end{array}$ & Renewable energy that is generated on-site. & 10 & Institutional research laboratories \\
\hline $\begin{array}{l}\text { Renewable energy } \\
\text { (offsite) }\end{array}$ & Renewable energy that is generated off-site. & 4 & Green electricity retailer \\
\hline Retrofits/installations & $\begin{array}{l}\text { These may involve, for example, improving or replacing lighting fixtures, } \\
\text { ventilation systems or windows and doors, or adding insulation } \\
\text { (Government of Canada, 2019). }\end{array}$ & 33 & Deep energy retrofit program \\
\hline Smart meters & $\begin{array}{l}\text { These allow for the implementation of time-of-use rates, and for customers } \\
\text { to manage their electricity consumption (IESO, 2021b). }\end{array}$ & 6 & Residential energy data and analytics \\
\hline Submetering & $\begin{array}{l}\text { This allows a landlord, property management firm, etc. to bill tenants for } \\
\text { individually measured electricity use (Navigant Consulting, 2016). }\end{array}$ & 1 & $\begin{array}{l}\text { Commercial building metering and } \\
\text { submetering }\end{array}$ \\
\hline
\end{tabular}

${ }^{a}$ An innovation may feature one or more aims; therefore, the total number of innovations in this table is $>122$ demand-side innovations.

assessed in this study, utilities are found to be the most frequent provider of innovations (38\%), followed by non-profits (31\%), governments $(30 \%)$, and then private businesses $(23 \%)$. Table 6 displays how availability, affordability, information, and involvement of the innovations vary according to the different types of innovation providers. Energy justice, according to our indicators, is being addressed in different proportions according to the type of innovation provider. Notably, many of the innovations provided by governments and utilities demonstrate availability, affordability, information and involvement, whereas innovations provided by non-profits and businesses see considerably more variation-for nonprofit-led innovations, information provisioning was present in $89 \%$ of the innovations, compared to $<40 \%$ for availability, 
TABLE 5 | The extent to which innovations demonstrate four indicators of energy justice ( $n=488)$.

\begin{tabular}{|c|c|c|c|c|c|c|}
\hline & & & Availability & Affordability & Information & Involvement \\
\hline \multirow[t]{6}{*}{ Innovations } & Yes & Count & 72 & 68 & 77 & 49 \\
\hline & & $\%$ & $59 \%$ & $56 \%$ & $63 \%$ & $40 \%$ \\
\hline & No & Count & 46 & 50 & 41 & 7 \\
\hline & & $\%$ & $38 \%$ & $41 \%$ & $37 \%$ & $6 \%$ \\
\hline & Unknown & Count & 4 & 4 & 4 & 66 \\
\hline & & $\%$ & $100 \%$ & $100 \%$ & $100 \%$ & $100 \%$ \\
\hline
\end{tabular}

TABLE 6 | Frequencies of justice indicators by provider type.

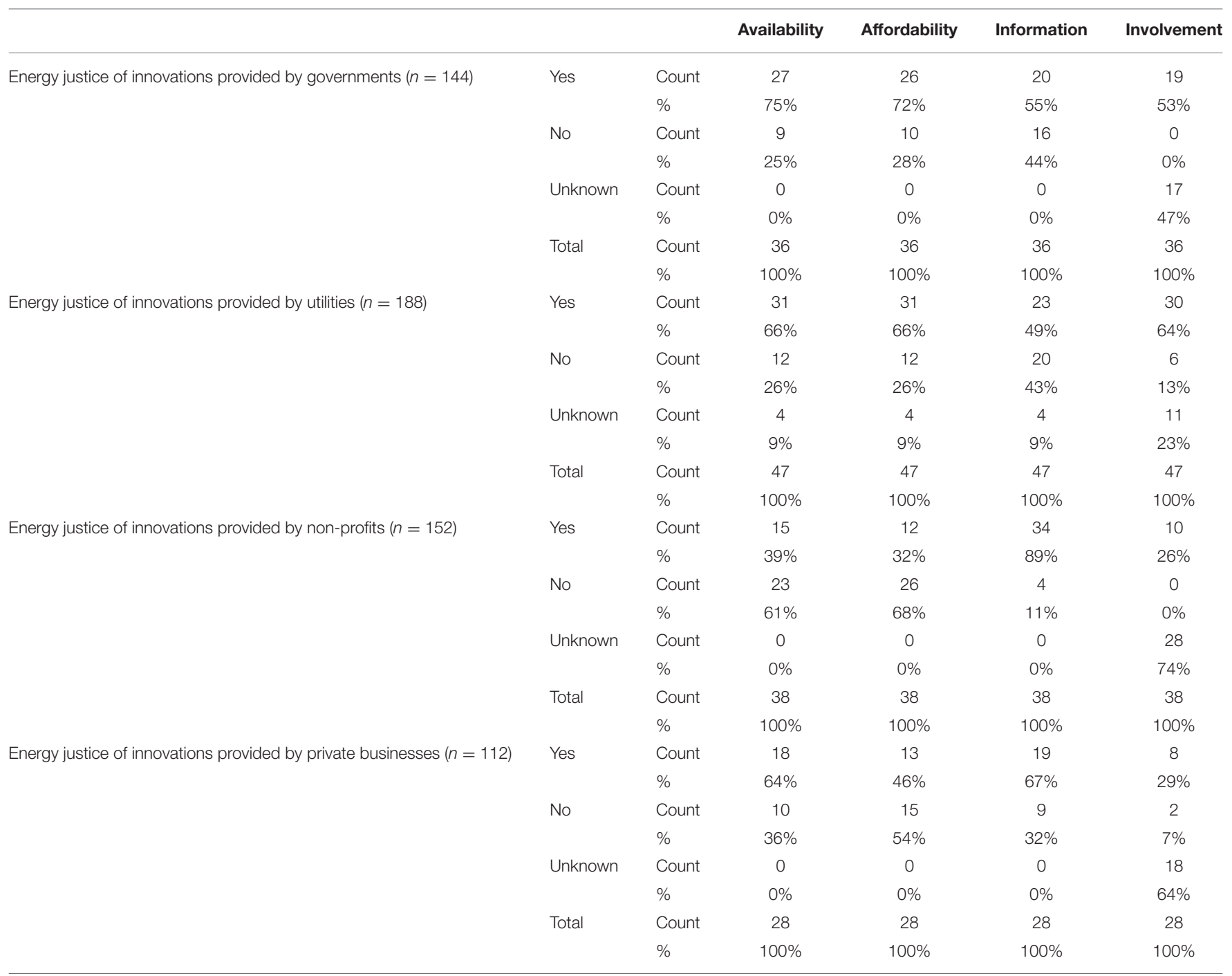

affordability, and involvement; and for business-led innovations, information was present for $67 \%$ of innovations, availability for $67 \%$, affordability for $46 \%$, and involvement for $29 \%$. A chi-square test of independence was conducted to analyze the frequencies for utilities and significant differences were found $\left(\chi^{2}=15.87, d f=6, p<0.05\right)$. Due to low expected 


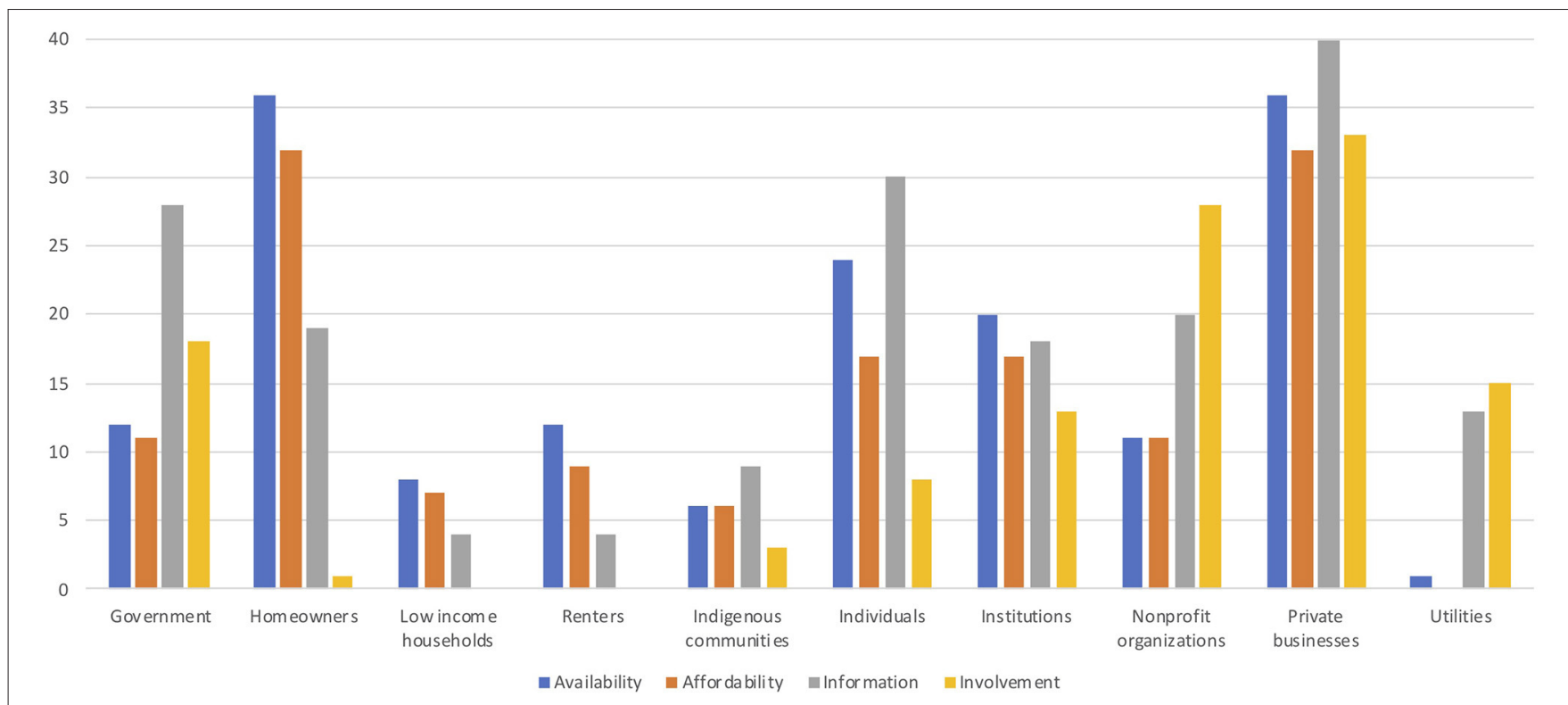

FIGURE 1 | Frequencies of energy justice indicators across innovations by user type.

frequencies ${ }^{2}$, this test was not performed for governments, non-profit organizations or private businesses.

Figure 1 displays the combined results for all types of innovation providers according to each type of innovation user. The following crosstabulation (Table 7) and corresponding clustered bar charts (Figures 2-5) display each type of innovation provider according to each type of innovation user, in order to demonstrate the provision of innovations by provider type for each user type. The table and charts are complementary to each other, where the table displays the relationship between innovation providers and users, with energy justice indicators collapsed. The clustered bar charts display the relationship between innovation providers and users, taking into account each of the energy justice indicators. The total count in the following tables and figures refer to the total possible outcomes, i.e., the number of innovations offered by each type of provider, across the four energy justice indicators, for each type of user. For example, 36 government-provided innovations, across 4 energy justice indicators, for 10 types of innovation providers $=1,440$ total possible outcomes.

The results show that while similar patterns are present across all innovation providers, the presence of energy justice is demonstrated most frequently in the innovations provided to private businesses (between 26 and 32\% of innovations), and least frequently in the innovations provided to low-income households (between 0 and 7\%), renters (between 2 and 10\%), and Indigenous communities (between 1 and 7\%), no matter the provider type. However, innovations provided by governments and utilities demonstrate the highest presence of energy justice

\footnotetext{
2"In contingency tables with more than one degree of freedom it is inappropriate if more than about one fifth of the cells have expected values $<5$ or any cell an expected value of $<1$ " (Swinscow, 1997, n.p.).
}

for low-income households (7 and 6\%, respectively), while utilities demonstrate the highest presence for renters (10\%) and Indigenous communities (7\%). Innovations provided by private businesses demonstrate the lowest presence of energy justice for these types $(0,2$, and $1 \%$, respectively). A chi-square test was conducted to examine the differences between the presence of justice indicators and significant differences were found for each innovation provider: governments $\left(\chi^{2}=73.80, d f=18, p<\right.$ $0.05)$; utilities $\left(\chi^{2}=103.86, d f=18, p<0.05\right)$; non-profits $\left(\chi^{2}\right.$ $=72.45, d f=18, p<0.05)$; and private businesses $\left(\chi^{2}=92.00\right.$, $d f=18, p<0.05)$.

Concerning information, where innovations provided by nonprofits and private businesses demonstrated the highest presence overall, innovations provided by private businesses demonstrate the highest presence for private business innovation users; and innovations provided by non-profits demonstrate the highest presence for private business and individuals.

Finally, utilizing data provided in Tables 7, 8 presents the combined frequencies of the presence of energy justice for innovation users across the four types of innovation providers, thereby accounting for all users and allowing for a direct comparison of providers. For example, from Table 7, governments provided innovations to 10 different user types, each accounting for 144 innovations and therefore a total of 1,440 innovations across all users, as reflected in Table 8. The combined frequencies included in this table thus lead to a higher number of possible outcomes for each innovation, resulting in higher percentage of "No" for all provider types. Results demonstrate that innovations provided by governments (14.58\%) and utilities (14.26\%) incorporate significantly more justice elements (across users) compared to the innovations provided by non-profits $(12.43 \%)$ and private businesses $(11.42 \%) ;\left(\chi^{2}=29.69, d f=6\right.$, $p<0.05)$. 
TABLE 7 | Crosstabulation of the presence of energy justice ${ }^{a}$ across innovation users by provider type.

\begin{tabular}{|c|c|c|c|c|c|c|c|c|c|c|c|c|}
\hline & & & Government & Homeowner & $\begin{array}{l}\text { Low-income } \\
\text { households }\end{array}$ & Renter & $\begin{array}{l}\text { Indigenous } \\
\text { communities }\end{array}$ & Individuals & Institutions & Non-profit & $\begin{array}{c}\text { Private } \\
\text { businesses }\end{array}$ & Utilities \\
\hline \multirow{8}{*}{$\begin{array}{l}\text { Energy justice of innovations } \\
\text { provided by governments } n= \\
1,440\end{array}$} & Yes & Count & 26 & 34 & 10 & 6 & 7 & 31 & 24 & 22 & 38 & 12 \\
\hline & & $\%$ & $18 \%$ & $24 \%$ & $7 \%$ & $4 \%$ & $5 \%$ & $22 \%$ & $17 \%$ & $15 \%$ & $26 \%$ & $8 \%$ \\
\hline & No & Count & 101 & 91 & 117 & 110 & 120 & 96 & 103 & 105 & 89 & 115 \\
\hline & & $\%$ & $70 \%$ & $63 \%$ & $81 \%$ & $76 \%$ & $83 \%$ & $67 \%$ & $72 \%$ & $73 \%$ & $62 \%$ & $80 \%$ \\
\hline & Unknown & Count & 17 & 19 & 17 & 28 & 17 & 17 & 17 & 17 & 17 & 17 \\
\hline & & $\%$ & $12 \%$ & $13 \%$ & $12 \%$ & $19 \%$ & $12 \%$ & $12 \%$ & $12 \%$ & $12 \%$ & $12 \%$ & $12 \%$ \\
\hline & Total & Count & 144 & 144 & 144 & 144 & 144 & 144 & 144 & 144 & 144 & 144 \\
\hline & & $\%$ & $100 \%$ & $100 \%$ & $100 \%$ & $100 \%$ & $100 \%$ & $100 \%$ & $100 \%$ & $100 \%$ & $100 \%$ & $100 \%$ \\
\hline \multirow{8}{*}{$\begin{array}{l}\text { Energy justice of innovations } \\
\text { provided by utilities } n=1,880\end{array}$} & Yes & Count & 25 & 45 & 12 & 19 & 14 & 24 & 23 & 31 & 60 & 15 \\
\hline & & $\%$ & $13 \%$ & $24 \%$ & $6 \%$ & $10 \%$ & $7 \%$ & $13 \%$ & $12 \%$ & $16 \%$ & $32 \%$ & $8 \%$ \\
\hline & No & Count & 140 & 110 & 147 & 131 & 151 & 141 & 142 & 134 & 105 & 150 \\
\hline & & $\%$ & $74 \%$ & $58 \%$ & $78 \%$ & $70 \%$ & $80 \%$ & $75 \%$ & $76 \%$ & $71 \%$ & $56 \%$ & $80 \%$ \\
\hline & Unknown & Count & 23 & 33 & 29 & 38 & 23 & 23 & 23 & 23 & 23 & 23 \\
\hline & & $\%$ & $12 \%$ & $18 \%$ & $15 \%$ & $20 \%$ & $12 \%$ & $12 \%$ & $12 \%$ & $12 \%$ & $12 \%$ & $12 \%$ \\
\hline & Total & Count & 188 & 188 & 188 & 188 & 188 & 188 & 188 & 188 & 188 & 188 \\
\hline & & $\%$ & $100 \%$ & $100 \%$ & $100 \%$ & $100 \%$ & $100 \%$ & $100 \%$ & $100 \%$ & $100 \%$ & $100 \%$ & $100 \%$ \\
\hline \multirow{8}{*}{$\begin{array}{l}\text { Energy justice of innovations } \\
\text { provided by non-profits } n= \\
1,520\end{array}$} & Yes & Count & 22 & 21 & 5 & 8 & 9 & 27 & 17 & 29 & 41 & 10 \\
\hline & & $\%$ & $14 \%$ & $14 \%$ & $3 \%$ & $5 \%$ & $6 \%$ & $18 \%$ & $11 \%$ & $19 \%$ & $27 \%$ & $7 \%$ \\
\hline & No & Count & 102 & 103 & 119 & 112 & 115 & 97 & 107 & 95 & 83 & 114 \\
\hline & & $\%$ & $67 \%$ & $68 \%$ & $78 \%$ & $74 \%$ & $76 \%$ & $64 \%$ & $70 \%$ & $63 \%$ & $55 \%$ & $75 \%$ \\
\hline & Unknown & Count & 28 & 28 & 28 & 32 & 28 & 28 & 28 & 28 & 28 & 28 \\
\hline & & $\%$ & $18 \%$ & $18 \%$ & $18 \%$ & $21 \%$ & $18 \%$ & $18 \%$ & $18 \%$ & $18 \%$ & $18 \%$ & $18 \%$ \\
\hline & Total & Count & 152 & 152 & 152 & 152 & 152 & 152 & 152 & 152 & 152 & 152 \\
\hline & & $\%$ & $100 \%$ & $100 \%$ & $100 \%$ & $100 \%$ & $100 \%$ & $100 \%$ & $100 \%$ & $100 \%$ & $100 \%$ & $100 \%$ \\
\hline \multirow{8}{*}{$\begin{array}{l}\text { Energy justice of innovations } \\
\text { provided by businesses } n= \\
1,120\end{array}$} & Yes & Count & 19 & 18 & 0 & 2 & 1 & 11 & 21 & 9 & 34 & 13 \\
\hline & & $\%$ & $17 \%$ & $16 \%$ & $0 \%$ & $2 \%$ & $1 \%$ & $10 \%$ & $18 \%$ & $8 \%$ & $30 \%$ & $12 \%$ \\
\hline & No & Count & 75 & 76 & 94 & 89 & 93 & 83 & 73 & 85 & 60 & 81 \\
\hline & & $\%$ & $67 \%$ & $68 \%$ & $84 \%$ & $79 \%$ & $83 \%$ & $74 \%$ & $65 \%$ & $75 \%$ & $54 \%$ & $72 \%$ \\
\hline & Unknown & Count & 18 & 18 & 18 & 21 & 18 & 18 & 18 & 18 & 18 & 18 \\
\hline & & $\%$ & $16 \%$ & $19 \%$ & $16 \%$ & $16 \%$ & $16 \%$ & $16 \%$ & $16 \%$ & $16 \%$ & $16 \%$ & $16 \%$ \\
\hline & Total & Count & 112 & 112 & 112 & 112 & 112 & 112 & 112 & 112 & 112 & 112 \\
\hline & & $\%$ & $100 \%$ & $100 \%$ & $100 \%$ & $100 \%$ & $100 \%$ & $100 \%$ & $100 \%$ & $100 \%$ & $100 \%$ & $100 \%$ \\
\hline
\end{tabular}

${ }^{a}$ Energy justice here is the combined score. 

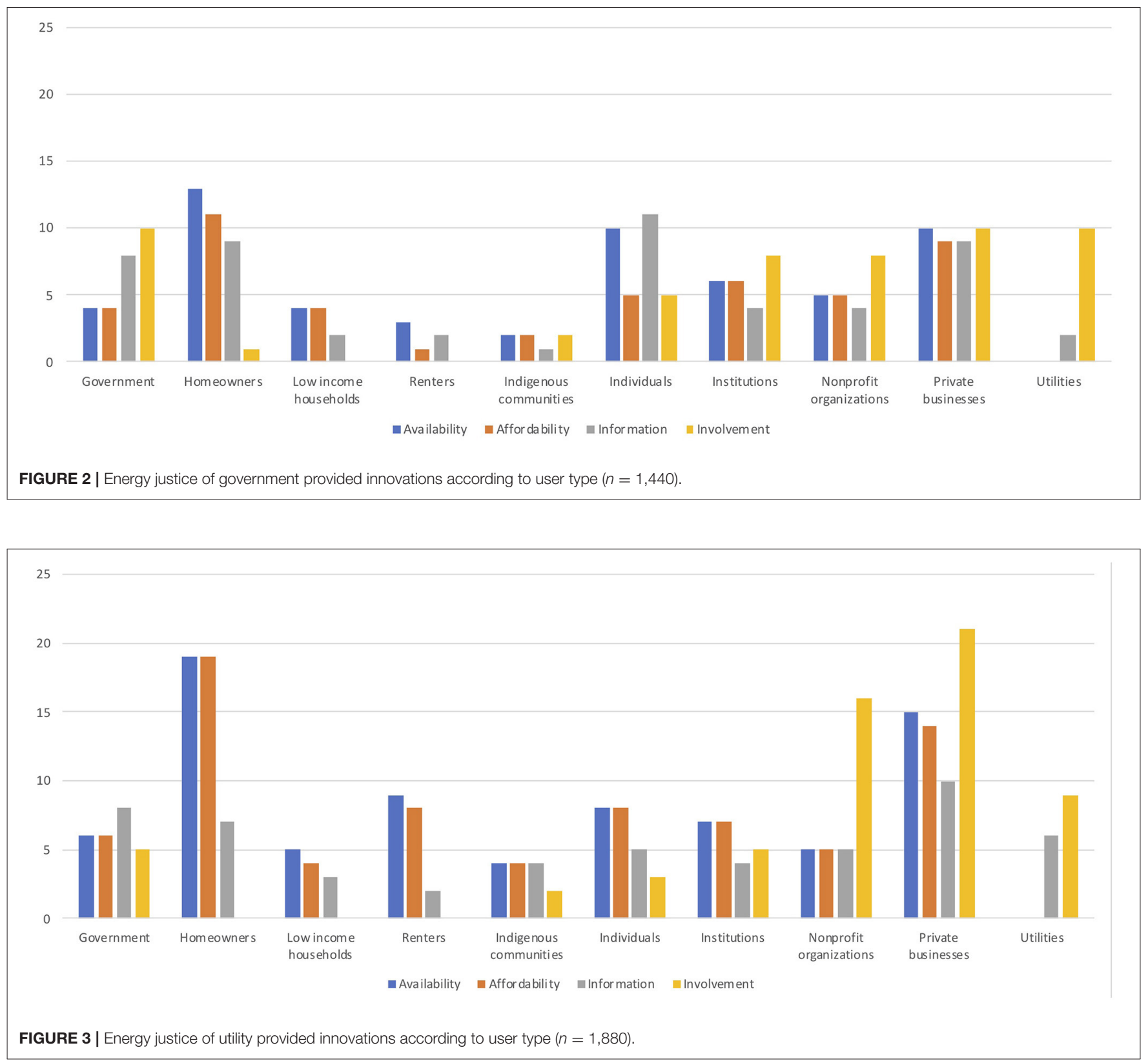

\section{DISCUSSION}

In order to address whether demand-side low-carbon energy innovations within Ontario's ETIS meet energy justice criteria, we employed indicators to measure energy justice across a range of innovations-the scope of which pertains to innovations identified specifically through Survey 1 and desk research from Hoicka et al. (2021) - provided to energy users. By applying indicators in this way, and by considering the relationship between the innovation user and innovation provider, our research identified potential justice gaps in the Ontario context. Thus, we contribute to literature by demonstrating how energy justice indicators can be derived from existing energy justice scholarship in order to better understand the relationships between innovation providers and innovation users within a given socio-technical system. The following section proceeds by first connecting our results to existing scholarship, including conversations about a Green New Deal in Canada; second, a reflection is provided on the design and application of indicators to measure energy justice generally, and in this particular context; last, some limitations of this study are discussed.

\section{Energy Justice in Ontario's ETIS}

Based on Survey 1 and desk research data, our results suggest that availability, affordability, and information are broadly being addressed within Ontario's ETIS, with a particular 

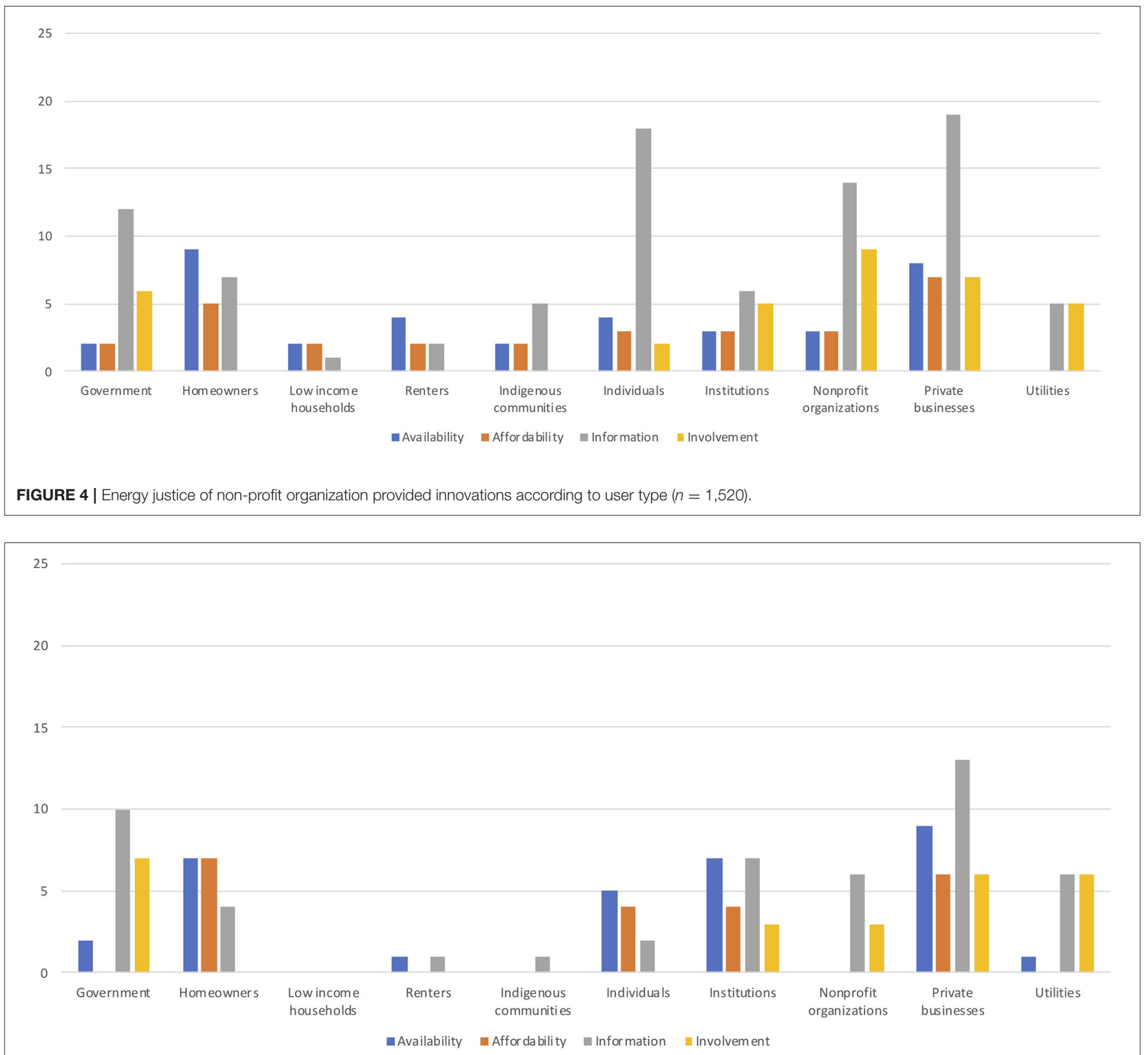

FIGURE 5 | Energy justice of private business provided innovations according to user type $(n=1,120)$.

emphasis on information. However, it should be noted that while the availability, affordability, and information indicators each demonstrated a majority "yes," these are not substantial majorities; thus, there remains opportunities for improvement in these areas. While a low presence of involvement was demonstrated overall, it is important to note that involvement was unknown for the majority of the innovations. Thus, it is unclear whether the results reveal low involvement, or merely reflect a lack of transparency surrounding involvement. However, a lack of transparency is nonetheless a concern, especially considering that procedural justice concerns have been raised in the Ontario context (Walker and Baxter, 2017; Rakshit et al., 2018).

Concerning the innovation users, our research finds that the ETIS may perpetuate inequities through an under-emphasis on potentially marginalized actors. In particular, the lack of innovations addressing affordability and availability for lowincome households and renters is a significant justice gap. Furthermore, these same types of actors were also very rarely stated to be included within involvement processes. Even the most represented indicator overall, information, was not found to specifically target people in vulnerable circumstances, including 
TABLE 8 | Combined frequencies across provider types.

\begin{tabular}{|c|c|c|c|c|c|c|}
\hline & & & Governments & Utilities & Non-profits & Private businesses \\
\hline \multirow[t]{5}{*}{ Energy justice of innovations ( $n=5,960$ ) } & Yes & Count & 210 & 268 & 189 & 128 \\
\hline & & $\%$ & $14.58 \%$ & $14.26 \%$ & $12.43 \%$ & $11.42 \%$ \\
\hline & & $\%$ & $72.71 \%$ & $71.86 \%$ & $68.88 \%$ & $72.22 \%$ \\
\hline & Unknown & Count & 183 & 261 & 284 & 183 \\
\hline & & $\%$ & $100 \%$ & $100 \%$ & $100 \%$ & $100 \%$ \\
\hline
\end{tabular}

low-income households and renters. Given that knowledgegaps pertaining to energy are associated with the inability to meaningfully participate in energy decision-making (Bozuwa, 2019), it seems critical that people in vulnerable circumstances are targeted with active information (e.g., energy audits or capacity-building initiatives), rather than merely having passive information on public websites.

Last, and perhaps most critical, concerning the relationship between the innovation provider and innovation user, we found that the type of innovation provider has potentially an important role in justice implications. Specifically, in the Ontario context, innovation providers that are governments, or some combination of publicly owned or heavily regulated, place a greater emphasis on justice when providing innovations, including the provision of innovations for people in vulnerable circumstances. These findings contribute to growing scholarship that considers the evolving relationships between innovation users and providers, including concerns about privatization and funding cuts to public services (Williams et al., 2014). Given that social enterprises (e.g., private businesses and nonprofit organizations) operate within the "third sector" of the economy, often where market or governmental failures exist in the provision of social welfare (Hillman et al., 2018), it is critical that any increased reliance on such actors does not exasperate justice concerns for people in vulnerable circumstances. Further, while non-profit organizations are argued to have filled the gaps of provincial government cost-cutting (Brouard et al., 2015), our analysis suggests that non-profit organizations are more likely to address knowledge gaps (i.e., through the provision of information) than any of the other indicators featured in our analysis. While information is an important component of procedural justice in that it can result in higher knowledge levels, there is debate as to the effectiveness of information, on its own, in changing behavior (Abrahamse et al., 2005). Given that the dominant formulation of funding for social enterprises in Ontario is one that focuses on the development of successful business ventures (Brouard et al., 2015) it is possible, due to lack of funding, that many non-profit organizations have limited capacity to address other energy justice indicators. Lastly, although social enterprises are increasingly key drivers of social progress (Hillman et al., 2018), the profit-motive present within social enterprises in Ontario context may disincentivize the provision of innovations to potentially vulnerable groups (i.e., those that are less likely to pay directly for innovations).

Notably, these findings reflect similar concerns regarding public services and social justice within ongoing conversations about a Green New Deal (GND) in Canada. In May 2019, the Coalition for a GND was formed, which provided a platform for discussions from townhalls across 150 communities, involving roughly 7,000 people. These participatory townhalls produced a range of "green lines" for a Canadian GND that emphasized the importance of a legally binding climate target in line with $1.5 \mathrm{C}$, public investment in renewable energy infrastructure, subsidies for greener technology, full access to quality public service, centering of marginalized communities and affordable energy-efficient housing (The Pact for a Green New Deal, 2019). Our finding, that government delivered, publicly owned or regulated innovation providers may more frequently address energy justice-conceptualized here as availability, affordability, information, and involvementfor marginalized communities, is therefore an important contribution to these ongoing conversations.

\section{Reflection on the Development and Application of Energy Justice Indicators}

Our research demonstrates how energy justice indicators can be derived from existing energy justice scholarship and applied to critical, current and understudied practical challenges. Such an approach contributes to literature because it provides a tool for researchers to measure energy justice within a given sociotechnical context. This approach is also important for policymakers, given that measurement can assist in the development of evidence-based decision-making.

Given the important findings within the Ontario context, our study suggests that the development and application of energy justice indicators could be applied to other sociotechnical systems to identify potential justice gaps. For example, such an approach could be incorporated into energy planning initiatives within a given locality (e.g., regional energy planning or local energy plans) in order to inform future program design and implementation. Depending on the particular challenges in a given context, the development of more or different indicators, e.g., derived from other energy justice principles, as well as different types of actors, may provide a more 
appropriate measure of energy justice. Furthermore, funders and program designers that are concerned with social justice may wish to employ a similar approach to ensure funding is addressing energy justice concerns, especially for people in vulnerable circumstances.

\section{Limitations}

In keeping with Sovacool and Dworkin's (2015) warning that there are limitations and difficulties associated with quantifying complex justice concerns, some limitations emerged throughout the development of our study. We found that indictors provide a useful, but limited, measure of justice-for example, our involvement indicator measured who is involved within consultation efforts, but did not consider the degree to which they were involved, nor whether any concerns actors raised were overcome. This limitation is made more noteworthy due to the use of binary indicators, which are limited in their ability to capture nuance. While binary indicators provide an achievable scope for the study of 122 innovations, a more indepth study involving a smaller sample of innovations may allow for a "deeper dive" with interviews and literature reviews for individual innovations. Thus, our research highlights the importance of complementary qualitative research, which can strengthen our understanding with investigations of particular innovations and activities within a socio-technical system.

Further limitations also arise with our reliance on publicly available data, which draws heavily on data from innovation providers. As such, there may be some limitations in our study's ability to reveal injustices if data were misrepresented on public-facing websites and documents. Furthermore, certain characteristics related to justice were absent from consideration given their absence in publicly available data. For example, this research method was largely unable to assess racial justice, despite environmental racism being prevalent and understudied in the Canadian context (Waldron, 2018). Such a gap is significant, and again highlights the importance of complementary qualitative research. Lastly, it was difficult to engage networks serving Indigenous communities, so innovations for these communities have potentially been overlooked, particularly those provided by private business and non-profit organizations offering innovations. The results in relation to Indigenous communities should therefore be viewed with caution.

\section{CONCLUSION}

Globally, and in Ontario, the diffusion of low-carbon innovations is ongoing. Although innovations offer a range of social and environmental benefits, there is no guarantee that benefits will be distributed justly. Innovations are emerging in the context of increased decentralization and oftentimes within the context of neoliberalism, including privatization and public service cuts. Given the evolving relationships between innovation users and innovation providers, as well as increased reliance on providers such as private businesses and non-profit organizations in the provision of social welfare, investigating energy justice in low-carbon energy innovations is critical to mitigate against emerging, as well as address existing, justice issues. To that end, our study presents a valuable strategy to develop and apply energy justice indicators to investigate the gaps across a given sociotechnical system, including the consideration of innovations, innovation users and innovation providers, and the relationships between them.

The findings of our study are now particularly relevant in Ontario due to the political shift which occurred at the end of the study timeline. In 2018, Ontario's Conservative party successfully campaigned on a promise to repeal significant provincial policy initiatives, including the GEGEA and the provincial cap and trade regulation that was funding the diffusion of low-carbon innovations. Hundreds of community renewable energy projects were canceled (Sharp, 2019). Considering this rollback of public investment and subsidies for a low-carbon energy transition, low-carbon innovations and climate change action, our study raises questions as to whether new justice gaps are being created. Commitments to energy justice reflect broader moral beliefs concerning social justice that, if agreed upon, ought to motivate corrective action (Galvin, 2019). It is therefore critical that these actors understand what justice gaps may emerge from the increased reliance on innovations they provide, in order for them to design and offer innovations accordingly.

\section{DATA AVAILABILITY STATEMENT}

The raw data supporting the conclusions of this article will be made available by the authors, without undue reservation.

\section{AUTHOR CONTRIBUTIONS}

SW: research conception and design, data analysis, interpretation, literature review, and writing. RD: writing, research design, and support with analysis and interpretation of results. $\mathrm{CH}$ : critical conceptual, writing support, and principal investigator of the larger project this study draws from. YZ: assistance with data collection, data analysis, and strong organizational support. M-LM: assistance with data collection and data analysis. All authors contributed to the article and approved the submitted version.

\section{FUNDING}

This work was supported by the Social Science and Humanities Research Council of Canada, the Smart Prosperity Institute, and the Faculty of Environmental Studies at York University (Grant Number 430-2015-00713).

\section{ACKNOWLEDGMENTS}

The authors acknowledge the input of Dr. Travis Gliedt on the surveys employed. We thank Dr. Jenny Lieu for input on the indicators. We also thank research assistants Alicia Campney, Sohrab Pathan, and Scott Harbinson for their work. We thank the reviewers for their helpful insights and suggestions. 


\section{REFERENCES}

Abrahamse, W., Steg, L., Vlek, C., and Rothengatter, T. (2005). A review of intervention studies aimed at household energy conservation. J. Environ. Psychol. 25, 273-291. doi: 10.1016/j.jenvp.2005.08.002

Baasch, S. (2020). An interdisciplinary perspective on environmental justice: integrating subjective beliefs and perceptions. Die Erde 151, 77-89. doi: $10.12854 /$ erde-2020-516

Bednar, D. J., and Reames, T. G. (2020). Recognition of and response to energy poverty in the United States. Nat. Energy 5, 432-439. doi: 10.1038/s41560-020-0582-0

Bordeaux, C., and Vesta, S. (2015). A Systems Change Approach to Energy Conservation. Toronto, ON: MaRS Discover District.

Bouzarovski, S., Petrova, S., and Sarlamanov, R. (2012). Energy poverty policies in the EU. Energy Policy 49, 76-82. doi: 10.1016/j.enpol.2012.01.033

Bowes, G. (2016). High Ontario hydro rates targeted in Hamilton protest. Hamilton News. Retrieved from: https://www.hamiltonnews.com/news-story/ 6849644-high-ontario-hydro-rates-targeted-in-hamilton-protest-sept-28/ (accessed November 20, 2020).

Bozuwa, J. (2019). Energy democracy: taking back power. The Next System Project. Retrieved from: https://thenextsystem.org/sites/default/files/2019-03/ EnergyDemocracy-2-star-Final.pdf (accessed July 20, 2021).

Brisbois, M. C. (2020). Decentralised energy, decentralised accountability? Lessons on how to govern decentralised electricity transitions from multi-level natural resource governance. Glob. Transit. 2, 16-25. doi: 10.1016/j.glt.2020.01.001

Brouard, F., McMurtry, J. J., and Vieta, M. (2015). Social enterprise models in Canada - Ontario. Can. J. Nonprofit Soc. Econ. Res. 6, 63-82. doi: $10.22230 /$ cjnser.2015v6nla195

Cadmus, Econoler and Apex Analytics (2018). Evaluation of 2018 Residential Programs. Prepared for the IESO. Retrieved from: https://www.ieso.ca/-/media/ Files/IESO/Document-Library/conservation/EMV/2018/2018-ResidentialPrograms-Evaluation-Report.ashx (accessed July 20, 2021).

Canada Energy Regulator (2017). Market Snapshot: Fuel Poverty Across Canada - Lower Energy Efficiency in Lower Income Households. Available online at: https://www.cer-rec.gc.ca/nrg/ntgrtd/mrkt/snpsht/2017/08-05flpvrt-eng. $\mathrm{html}$ ?=undefinedandwbdisable=true (accessed September 25, 2020).

Canadian Rental Housing Index (2018). Rental Housing Data. Retrieved from: http://www.rentalhousingindex.ca/en/\#renter_prov (accessed October 31, 2020).

Catney, P. C., MacGreggor, S., Dobson, A., Hall, S. M., Royston, S., Robinson, Z., et al. (2014). Big society, little justice? Community renewable energy and the politics of localism. Local Environ. 19, 715-730. doi: $10.1080 / 13549839.2013 .792044$

Community Conservation Manager (2018). Peaksaver is Back...with a PLUS. Retrieved from: https://www.ccmanager.ca/peaksaver.asp?u=322 (accessed April 6, 2018).

Crawley, M. (2014). Smart meter installation cost Ontario nearly double orginal projection: AG. CBC News. Retrieved from: https://www.cbc.ca/news/canada/ toronto/smart-meter-installation-cost-ontario-nearly-double-originalprojection-ag-1.2866207\#:|sim:text=The\%20auditor\%20reveals\%20it\%20cost, be $\% 20$ closer\% 20 to $\% 20 \% 241 \% 20$ billion (accessed July 20, 2021).

CUSP (2019). Energy Poverty in Canada: CUSP Backgrounder. Retrieved from: https://energypoverty.ca/backgrounder.pdf (accessed July 20, 2021).

Drehobl, A., Ross, L., and Ayala, R. (2020). How High Are Household Energy Burdens? American Council for and Energy-Efficient Economy. Retrieved from: https://www.aceee.org/sites/default/files/pdfs/u2006.pdf (accessed July 20, 2021).

Fraune, C. (2015). Gender matters: Women, renewable energy, and citizen participation in Germany. Energy Res. Soc. Sci. 7, 55-65. doi: $10.1016 /$ j.erss.2015.02.005

Galvin, R. (2019). What does it mean to make a moral claim? A Wittgensteinian approach to energy justice. Energy Res. Soc. Sci. 54, 176-184. doi: 10.1016/j.erss.2019.04.018

Gillard, R., Snell, C., and Bevan, M. (2017). Advancing an energy justice perspective of fuel poverty: household vulnerability and domestic retrofit policy in the United Kingdom. Energy Res. Soc. Sci. 29, 53-61. doi: 10.1016/j.erss.2017. 05.012
Gliedt, T., Hoicka, C. E., and Jackson, N. (2018). Innovation intermediaries accelerating environmental sustainability transitions. J. Clean. Product. 174, 1247-1261. doi: 10.1016/j.jclepro.2017.11.054

Gliedt, T., and Parker, P. (2014). Green community entrepreneurship 2.0 Collective response or individual adaptation strategy to funding cuts in Canada (2006-2012). Int. J. Soc. Econ. 41, 609-625. doi: 10.1108/IJSE-052013-0125

Government of Canada (2017). About Renewable Energy. Retrieved from: https://www.nrcan.gc.ca/our-natural-resources/energy-sources-distribution/ renewable- energy/about-renewable-energy/7295 (accessed February 4, 2021).

Government of Canada (2019). Retrofitting. Retrieved from: https://www.nrcan.gc. ca/retrofitting/20707 (accessed February 4, 2021).

Government of Ontario (2019). 2013 State of the Sector: Profile of Ontario's Notfor-Profits and Charitable Organizations. Retrieved from: https://www.ontario. $\mathrm{ca} /$ page/2013-state-sector-profile- ontarios-not-profits-and-charitableorganizations- executive-summary (accessed October 31, 2020).

Grubler, A., and Wilson, C. (2013). Energy Technology Innovation. Cambridge University Press. doi: 10.1017/CBO9781139150880

Habitat for Humanity Halton-Mississauga (2018). Letter from CEO: Energy Poverty an Increasing Reality in Ontario. Retrieved from: https://habitathm.ca/ letter-from-ceo-energy-poverty-an-increasing-reality-in-ontario/ (accessed February 6, 2021).

Hannon, M. J., Skea, J., and Rhodes, A. (2014). "Facilitating and coordinating UK energy innovation through systemic innovation intermediaries," in 5th International Conference Energy and Sustainability (Utrecht), 27-29.

Heffron, R. L., and McCauley, D. (2017). The concept of energy justice across the disciplines. Energy Policy 105, 658-667. doi: 10.1016/j.enpol.2017. 03.018

Hepburn, N. (2013). "The impact of policy networks on ontario's research and innovation infrastructure: explaining the development of the ontario network of excellence," in Annual Meeting of the Canadian Political Science Association (Victoria, BC). Retrieved from: https://www.cpsa-acsp.ca/papers2013/Hepburn.pdf (accessed July 20, 2021).

Hillman, J., Morrissey, J. E., and Axon, S. (2018). Social enterprise as a potential niche innovation breakout for low carbon transition. Energy Policy 117, 445-456. doi: 10.1016/j.enpol.2018.03.038

Hoicka, C. E., Das, R. R., Zhao, Y., McMaster, M. L., Lieu, J., and Wyse, S. M. (2021). Methodology to identify demand-side low-carbon innovations and their potential impact on socio-technical energy systems. MethodsX 8:101295. doi: 10.1016/j.mex.2021.101295

Hoicka, C. E., and MacArthur, J. (2021). "The infrastructure for electricity," in The Oxford Handbook of Energy Politics (Oxford University Press). Available online at: https://www.oxfordhandbooks.com/view/10.1093/oxfordhb/ 9780190861360.001.0001/oxfordhb-9780190861360-e-33

Hoicka, C. E., Parker, P., and Andrey, J. (2014). Residential energy efficiency retrofits: how program design affects participation and outcomes. Energy Policy 65, 594-607. doi: 10.1016/j.enpol.2013.10.053

IESO (2017). What is the Education and Capacity Building Program? Retrieved from: http://www.ieso.ca/en/get-involved/funding-programs/education-andcapacity-building-program/overview (accessed December 12, 2017).

IESO (2021a). What's the Big Deal About Energy Storage? Retrieved from: https:// ieso.ca/en/Powering-Tomorrow/2018/Whats-the-big-deal-about-energystorage (accessed February 4, 2021).

IESO (2021b). Smart Metering Entity. Retrieved from: https://www.ieso.ca/en/ sector-participants/smart-metering-entity/sme-overview (accessed February 4, 2021).

IndEco and Navigant Consulting (2017). Demand Side Management (DSM) in North American Gas Utilities. Retrieved from: https://www.indeco.com/ideas/ dsmsurvey/ (accessed July 20, 2021).

Jenkins, K. (2018). Setting energy justice apart from the crowd: lessons from environmental and climate justice. Energy Res. Soc. Sci. 39, 117-121. doi: 10.1016/j.erss.2017.11.015

Jenkins, K., McCauley, D., Heffron, R., Stephan, H., and Rehner, R. (2016). Energy Justice: a conceptual review. Energy Res. Soc. Sci. 11, 174-182. doi: 10.1016/j.erss.2015.10.004

Johnson, D., and Lewis, A. (2017). "Organizing for energy democracy in rural electric cooperatives," in Energy Democracy, eds D. Fairchild and A. 
Weinrub (Washington, DC: Island Press), 93-112. doi: 10.5822/978-1-61091852-7_6

Jordaan, S. M., Romo-Rabago, E., McLeary, R., Reidy, L., Nazari, J., and Herremans, I. M. (2017). The role of energy technology innovation in reducing greenhouse gas emissions: a case study of Canada. Renew. Sustain. Energy Rev. 78, 1397-1409. doi: 10.1016/j.rser.2017. 05.162

Karakaya, E., Hidalgo, A., and Nuur, C. (2014). Diffusion of eco-innovations: a review. Renew. Sustain. Energy Rev. 33, 392-399. doi: 10.1016/j.rser.2014. 01.083

Köhler, J., Geels, F. W., Kern, F., Markard, K., Onsongo, E., Wieczorek, A., et al. (2019). An agenda for sustainability transitions research: state of the art and future directions. Environ. Innov. Soc. Transit. 31, 1-32. doi: $10.1016 /$ j.eist.2019.01.004

Lacey-Barnacle, M., and Bird, C. M. (2018). Intermediating energy justice? The role of intermediaries in the civic energy sector in a time of austerity. Appl. Energy 226, 71-81. doi: 10.1016/j.apenergy.2018. 05.088

Matti, C., Consoli, D., and Uyarra, E. (2017). Multi level policy mixes and industry emergence: the case of wind energy in Spain. Environ. Plan. C Politics Space 35, 661-683. doi: 10.1177/0263774X16663933

McCauley, D., Heffron, R. J., Stephan, H., and Jenkins, K. (2013). Advancing Energy Justice: The Triumvirate of Tenets. Available online at: https://www. researchgate.net/publication/259459020 (accessed July 20, 2021).

McCauley, D., Ramasar, V., Heffron, R., Sovacool, B., Mebratu, D., and Mundaca, D. (2018). Energy justice in the transition to low carbon energy systems: exploring key themes in the social sciences. Appl. Energy 223-234, 916-921. doi: 10.1016/j.apenergy.2018.10.005

McRobert, D., Tennet-Riddell, J., and Walker, C. (2016). Ontario's Green Economy and Green Energy Act: Why a Well-Intentioned Law is Mired in Controversy and Opposed by Rural Communities. RELP, 1-22. Available online at: https://www.academia.edu/30409207/Ontario_s_Green_Energy_and_Green_ Economy_Act_Why_a_Well-Intentioned_Law_is_Mired_in_Controversy_ and_Opposed_by_Rural_Communities

Ministry of Energy (2013). Ontario Supporting Local Energy Planning in Municipalities and Aboriginal Communities. Retrieved from: https://news. ontario.ca/mei/en/2013/08/ontario-supporting-local-energy-planning-inmunicipalities-and-aboriginal-communities.html (accessed June 26. 2018).

Ministry of Municipal Affairs and Housing (2012). MUNICIPALACT, 2001 - Local Improvement Charges - Priority Lien Status, O. Reg. 322/12 \$.

Ministry of Transportation (2009). About Low Carbon Vehicles. Retrieved from: http://www.mto.gov.on.ca/english/vehicles/electric/about-electric-vehicle. shtml (accessed February 4, 2021).

Navigant Consulting (2016). Evaluation of the Impact of Sub-Metering on Multi-Residential Electricity Consumption and the Potential Economic and Environmental Impact on Ontario. Repor prepared for Enercare Connections Inc. Retrieved from: https://www.enercare.ca/sites/default/files/assets/library/ pdfs/enercare-navigant-sub-metering-report-04-19-16-final-v2.pdf (accessed July 20, 2021).

OEB (2008). Demand Side Management Guidelines for Natural Gas Utilities. EB2008-0346. Retrieved from: https://www.oeb.ca/oeb/_Documents/Regulatory/ DSM_Guidelines_for_Natural_Gas_Utilities.pdf (accessed July 20, 2021).

OEB (2012). Ontario's Energy Sector. Retrieved from: https://www.oeb.ca/aboutus/mission-and-mandate/ontarios-energy-sector (accessed October 5, 2020).

OEB (2020). Ontario's Energy Sector. Retrieved from: https://www.oeb.ca/aboutus/mission-and-mandate/why-do-we-regulate (accessed November 20, 2020).

OECD (2009) Eco-Innovation in Industry: Enabling Green Growth. Paris: OECD.

Ontario (2008). Seizing Global Opportunities: Ontario's Innovation Agenda. Retrieved from: http://www.ontario.ca/innovation (accessed June 28, 2018).

Ontario Distribution Sector Review Panel (2012). Renewing Ontario's Electricity Distribution Sector: Putting the Consumer First. Retrieved from: https:// www.thinkingpower.ca/PDFs/FeaturedNews/Report\%20of\%20the\%20Ontario \%20Distribution\%20Sector\%20Review\%20Panel.pdf (accessed July 20, 2021).

Ontario Minister of Energy (2004). Minister's Directive issued under Section 27.1 of the Ontario Energy Board Act, 1998. Toronto, ON.

Ontario Ministry of Energy (2017). Delivering Fairness and Choice: Ontario's Long-Term Energy Plan 2017. Retrieved from: https://files.ontario.ca/books/ ltep2017_0.pdf (accessed July 20, 2021).
O'Shea, S. (2016). Angry rural Ontario hydro customers stage protest over rising costs. Global News. Retrieved from: https:/globalnews.ca/news/2961537/ angry-rural-hydro-customers- say-enough-during-rally-in-bancroft-ont/ (accessed November 21, 2020).

Palensky, P., and Kupzog, F. (2013). Smart grids. Ann. Rev. Environ. Resour. 38, 201-226. doi: 10.1146/annurev-environ-031312102947

Rakshit, R., Shahi, C., (Peggy) Smith, M. A., and Cornwell, A. (2018). Bridging gaps in energy planning for first nation communities. Strategic Plan. Energy Environ. 37, 1-42. doi: 10.1080/10485236.2018. 11958658

Reames, T. G. (2016). A community-based approach to low-income residential energy efficiency participation barriers. Local Environ. 21, 1449-1466. doi: 10.1080/13549839.2015.1136995

Rezaie, B., and Rosen, M. A. (2012). District heating and cooling: review of technology and potential enhancements. Appl. Energy 93, 2-10. doi: 10.1016/j.apenergy.2011.04.020

Schmidt, S., and Pardo, Y. (2014). "Normative data," in Encyclopedia of Quality of Life and Well-Being Research, ed A. C. Michalos (Dordrecht: Springer). doi: 10.1007/978-94-007-0753-5_1964

Scott, A. J. (2016). In the Dark: An Exploration of the Human Rights Implications of Energy Poverty in Rural Ontario. [research paper submitted to the Faculty of Graduate and Postdoctoral Studies In partial fulfillment of the requirements For the LL.M. degree in Law, University of Ottawa]. Retrieved from: https:// cela.ca/wp-content/uploads/2019/07/In-the-Dark.pdf (accessed July 20, 2021).

Sharp, A. (2019). Ontario auditor general slams Ford's climate policies. National Observer. Retrieved from: https://www.nationalobserver.com/2019/12/04/ news/ontario-auditor-general-slams-doug-ford-climate-policies (accessed November 22, 2020).

Sims Gallagher, K., Grübler, A., Kuhl, L., Nemet, G., and Wilson, C. (2012). The energy technology innovation system. Ann. Rev. Environ. Resour. 37, 137-162. doi: 10.1146/annurev-environ-060311-133915

Sovacool, B., and Dworkin, M. (2015). Energy Justice: conceptual insights and practical applications. Appl. Energy 142, 435-444. doi: 10.1016/j.apenergy.2015.01.002

Sovacool, B. K., Burke, M., Baker, L., Kotikalapudi, C. K., and Wlokas, H. (2017). New frontiers and conceptual frameworks for energy justice. Energy Policy 105, 677-691. doi: 10.1016/j.enpol.2017.03.005

Sovacool, B. K., Heffron, R. J., McCauley, D., and Goldthau, A. (2016). Energy decisions reframed as justice and ethical concerns. Nat. Energy 1:16024. doi: 10.1038/nenergy.2016.24

Sovacool, B. K., Lipson, M. M., and Chard, R. (2019a). Temporality, vulnerability, and energy justice in household low carbon innovations. Energy Policy 128, 495-504. doi: 10.1016/j.enpol.2019.01.010

Sovacool, B. K., Martiskainen, M., Hook, A., and Baker, L. (2019b). Decarbonization and its discontents: a critical energy justice perspective on four low carbon transitions. Clim. Change 155, 581-619. doi: 10.1007/s10584-019-02521-7

Statistics Canada (2017). Census Profile, 2016 Census: Ontario. Retrieved from: https://www12.statcan.gc.ca/census-recensement/2016/dp-pd/ prof $/$ details/page.cfm?Lang=EandGeo1 $=$ PRandCode1 $=35$ andGeo $2=$ PRandCode2 $=01$ andData $=$ CountandSearchText $=$ OntarioandSearchType $=$ BeginsandSearchPR=01andB1=AllandTABID=1 (accessed October 5, 2020).

Swinscow, S. (1997). Statistics at Square One. London: BMJ Publ. Group. Retrieved from: https://www.bmj.com/about-bmj/resources-readers/publications/ statistics-square-one (accessed July 20, 2021).

The Pact for a Green New Deal (2019). What Did we Hear at the Pact for a Green New Deal Town Halls? Retrieved from https://act.greennewdealcanada. ca/what-we-heard/ (accessed November 20, 2020).

Toronto (2006). Making a Sustainable City Happen: The Toronto Green Development Standard. Retrieved from: https://www.toronto.ca/legdocs/2006/ agendas/committees/ren/ren060710/it003.pdf (accessed July 20, 2021).

Toronto (2017). Home Energy Loan Program. https://www.toronto.ca/servicespayments/water-environment/environmental-grants-incentives-2/homeenergy-loan-program-help/ (accessed December 12, 2017).

Waldron, I. R. G. (2018). There's Something in the Water: Environmental Racism in Indigenous and Black Communities. Winnipeg, MB; Black Point, NS: Fernwood Publishing. 
Walker, C. J. R., and Baxter, J. (2017). Wind energy policy, development, and justice in Ontario and Nova Scotia, Canada: a comparison of technocratic and community-based siting processes. Electron. Thesis Dissert. Repository 4696. Available online at: https://ir.lib.uwo.ca/cgi/viewcontent.cgi?article $=6398 \&$ context=etd

Williams, A., Goodwin, M., and Cloke, P. (2014). Neoliberalism, big society, and progressive localism. Environ. Plann. A 46, 2798-2815. doi: 10.1068/a130119p

Wilson, C. (2018). Disruptive low-carbon innovations. Energy Res. Soc. Sci. 37, 216-223. doi: 10.1016/j.erss.2017. 10.053

Wolsink, M. (2012). The research agenda on social acceptance of distributed generation in smart grids: renewable as common pool resources. Renew. Sustain. Energy Rev. 16, 822-835. doi: 10.1016/j.rser.2011. 09.006

Wyse, S. M., and Hoicka, C. E. (2019). "By and for local people": assessing the connection between local energy plans and community energy. Local Environ. 24, 883-900. doi: 10.1080/13549839.2019. 1652802
Conflict of Interest: The authors declare that the research was conducted in the absence of any commercial or financial relationships that could be construed as a potential conflict of interest.

Publisher's Note: All claims expressed in this article are solely those of the authors and do not necessarily represent those of their affiliated organizations, or those of the publisher, the editors and the reviewers. Any product that may be evaluated in this article, or claim that may be made by its manufacturer, is not guaranteed or endorsed by the publisher.

Copyright $\odot 2021$ Wyse, Das, Hoicka, Zhao and McMaster. This is an open-access article distributed under the terms of the Creative Commons Attribution License (CC $B Y)$. The use, distribution or reproduction in other forums is permitted, provided the original author(s) and the copyright owner(s) are credited and that the original publication in this journal is cited, in accordance with accepted academic practice. No use, distribution or reproduction is permitted which does not comply with these terms. 